\title{
Relationships between postruminal casein infusion and milk production, and concentrations of plasma amino acids and blood urea in dairy cows: A multilevel mixed-effects meta-analysis
}

\author{
R. Martineau, ${ }^{\star 1}$ D. R. Ouellet, $†$ E. Kebreab,‡ R. R. White, $\S$ and H. Lapierre† \\ *Valacta, Dairy Production Centre of Expertise Québec-Atlantic, Sainte-Anne-de-Bellevue, QC, Canada H9X 3R4 \\ †Agriculture and Agri-Food Canada, Sherbrooke, QC, Canada J1M 0C8 \\ ‡Department of Animal Science, University of California, Davis 95616 \\ $\S$ Department of Animal and Poultry Sciences, Virginia Tech, Blacksburg 24061
}

\section{ABSTRACT}

The relationships between postruminal casein infusion and production variables and concentrations of plasma AA and blood urea were evaluated using multilevel mixed-effects models derived from literature data collected in dairy cows. The data set contained 147 treatment means [i.e., 66 controls (CTL) and 81 caseininfused (CAS) means]. Each CAS mean was paired with its corresponding CTL mean to create 81 mean differences (CAS minus CTL), which were analyzed as absolute and percentage-based units (i.e., percentage increase or decrease in CAS relative to CTL). The primary variable of interest was the difference in estimated metabolizable protein (MP) supply $(\Delta \mathrm{MP})$ between CAS and CTL. The other explanatory variables were based on levels in CTL: MP supply, MP balance, the ratio of duodenal microbial protein (MCP) to MP supply (MCPMP), the stage of lactation (early or mid/late) and the type of forage (grass/legume- or corn silage-based). The MP supply and MP balance influenced negatively the relationship between $\triangle \mathrm{MP}$ and the response of true protein yield. Responses of milk urea, blood urea, and plasma urea cycle AA concentrations were associated positively with $\triangle \mathrm{MP}$, indicating that a large amount of infused AA was catabolized to urea. Responses of plasma essential AA concentrations were related positively to $\Delta \mathrm{MP}$. The relative effect of $\Delta \mathrm{MP}$ was highest for responses of plasma His concentration in cows fed grass/legume-based diets and at high MCPMP ratios. This relationship suggests that positive responses of plasma His concentrations are associated with diets relying heavily on microbial protein synthesis (high MCP), low in crude protein (low estimated MP supply), or both. The relationship between $\Delta \mathrm{MP}$

Received August 1, 2016.

Accepted May 17, 2017.

${ }^{1}$ Corresponding author: roger.martineau@canada.ca and responses of plasma group $2 \mathrm{AA}$ (Ile, Leu, Lys, and Val) concentrations was approximately 2 times greater than that for group $1 \mathrm{AA}$ (His, Met, and Phe+Tyr) at mean MCPMP and MP supply. This could reflect the low hepatic removal group 2 AA compared with group $1 \mathrm{AA}$ in dairy cows. Collectively, these results provide novel information on how dietary and cow conditions may alter responses to protein supplementation.

Key words: dairy cow, meta-analysis, casein, amino acid, protein yield

\section{INTRODUCTION}

More than 2 decades ago, refined models were introduced to estimate protein supply and requirements for dairy cows. In these models, the supply of protein was no longer based on feed intake and the dietary concentration of CP (or ruminal degradability of $\mathrm{CP}$ ), but rather on estimates of the flows of digestible protein and EAA. For example, the MP system from the NRC (2001) model and the protein digestible in the intestine system from Institut National de la Recherche Agronomique (INRA, 2007) proved to be major improvements over previous feeding systems. Both systems took into account the rumen degradability of $\mathrm{CP}$ and the contribution of microbial protein and RUP to MP supply. As a result, the net portal absorption of AA-N in ruminants is predicted more reliably and with less bias by MP supply estimations than by diet characteristics alone (Martineau et al., 2014).

Most models used to balance dairy rations use fixed efficiencies for the conversion of MP absorbed from the small intestine into MP required to support anabolic functions (Lapierre et al., 2014a). For example, one can compute that $1.5 \mathrm{~kg}$ of absorbed MP is required per kilogram milk true protein yield (MTPY), assuming a fixed efficiency of 0.67 as used in NRC (2001). This is despite the fact that research previous to NRC (2001) clearly indicated that the marginal recovery of 
absorbed AA into milk protein diminishes as the supply of duodenal protein increases (Whitelaw et al., 1986; Hanigan et al., 1998). Consequently, MTPY is overestimated at high MP supply and underestimated at low MP supply using fixed efficiencies. Not surprisingly, recent models are moving toward the implementation of variable efficiencies for the prediction of production responses to incremental MP or protein digestible in the intestine supply [e.g., NorFor (Volden et al., 2011) and new French feeding system (Sauvant et al., 2015)]. However, to be robust in the field, efficiencies need to be predicted with high accuracy. One way to increase the predictive accuracy for efficiencies is to study the response of MTPY to known increments of MP supply. Methodologically, more consistent production responses are expected in experiments where a known amount of MP is infused postruminally compared with experiments where differences in MP supply result from variations of dietary treatments (DePeters and Cant, 1992; Aikman et al., 2002; Chamberlain and Yeo, 2003).

Dose-response of MTPY to incremental MP supply can be achieved by postruminal casein infusion. Casein offers several advantages over other protein sources, as it is highly digestible and has an optimal AA profile for milk protein synthesis (Clark, 1975; Bionaz et al., 2012). Moreover, minimal effects of casein on rumen metabolism and feed intake are expected with postruminal infusion (Huhtanen and Hristov, 2010).

To our knowledge, the benefits associated with duodenal infusion of casein over oral administration were first demonstrated by Chalmers et al. (1954) in sheep, based on $\mathrm{N}$ balance and ruminal ammonia data. In dairy cows, Broderick et al. (1970) reported that abomasal infusion of sodium caseinate $(800 \mathrm{~g} / \mathrm{d})$ decreased grain intake but increased milk protein yield and plasma concentrations of Ile, Leu, Phe, Val, and total EAA. Clark (1975) reviewed 7 studies and reported that postruminal casein infusion had the potential to increase milk yield (up to $4 \mathrm{~kg} / \mathrm{d}$ ) and milk protein yield (by 10 to 15\%). These findings prompted more research with postruminal casein infusion under various experimental conditions.

Despite the large body of literature published since 1970, a comprehensive meta-analytic review is lacking on the relationships between postruminal casein infusion and variables on production and concentrations of plasma AA and blood urea in dairy cows. Some issues with previously published reviews include (1) part of the literature was reviewed at time of publishing (e.g., Hanigan et al., 1998; Patton et al., 2015); (2) experiments with postruminal casein infusion and AA infused i.v. were aggregated (e.g., Doepel et al., 2004; Lapierre et al., 2012); or (3) only the relationship between casein infusion and milk protein yield was evaluated (e.g.,
Huhtanen and Hristov, 2010). Recently, Patton et al. (2015) reported the relationships between casein infusion and production variables and plasma EAA concentrations, but included no mention of the influence of other factors (e.g., casein infusion rate).

The relationship between casein infusion rate (as a primary variable of interest) and the response of DMI was reported in a previous paper (Martineau et al., 2016). Martineau et al. (2016) indicated that for outcomes other than the response of DMI, the primary variable of interest should be the difference in estimated MP supply ( $\Delta \mathbf{M P})$ between casein-infused and control treatments due to within-study differences in DMI and also to ration composition, in rare occurrences (e.g., Rogers et al., 1984).

Our hypothesis was that summarizing results from several casein infusion experiments would allow for determination of the response of several variables to incremental MP supply and the possible influence of explanatory variables on these relationships. For example, the supply and balance in MP, the ratio of microbial CP to MP supply (MCPMP), the stage of lactation (early or mid/late), and the type of forage (grass/legume- or corn silage-based diets) might influence the relationships between $\triangle \mathrm{MP}$ and responses of MTPY and plasma EAA concentrations. Therefore, the objectives of the current meta-analysis were to (1) review the relationships between $\triangle \mathrm{MP}$ and the responses of production variables and plasma AA and blood urea concentrations in lactating dairy cows; (2) consider $\Delta \mathrm{MP}$ as the primary variable of interest in all models; and (3) explore the influence of other explanatory variables on the relationship between $\Delta \mathrm{MP}$ and each response.

\section{MATERIALS AND METHODS}

\section{Database}

The Scopus online database was searched in November 2015 for studies where casein was infused postruminally in lactating dairy cows with the terms "casein or caseinate," "abomasal or duodenal," and "cow or dairy." Inclusion criteria were (1) a treatment consisting of intact casein infused postruminally (CAS); (2) a control treatment (CTL) consisting of water or saline infused postruminally; (3) number of experimental units (n) for CAS and CTL; (4) a measure that allows calculation of the variance of the mean difference (CAS minus CTL); (5) information on feed intake, feed ingredients, or ration composition; (6) estimated MP supply in CTL $>800 \mathrm{~g} / \mathrm{d}$; and (7) published in English or French.

The infusion of a substrate in a single treatment was an exclusion criterion unless it was infused in both CAS 
and CTL treatments [e.g., glucose was infused at the same rate in CAS and CTL treatments in Clark et al. (1977)]. An exception was made for treatments from Schwab et al. (1992), as DL-Met was infused in CTL but not in CAS. Plasma AA concentrations were assumed to be in micromoles per deciliter (not $\mu \mathrm{mol} / \mathrm{mL}$ ) in Seymour et al. (1990) and in micromolar (not mmol/L) in Choung and Chamberlain (1993b). If not reported in the publication, plasma concentrations of group 1 AA (His, Met, and Phe+Tyr), group 2 AA (Ile, Leu, Lys, and Val), and urea cycle AA (Arg, Cit, and Orn; URCY) were calculated by summation of constituent AA. The data from 42 publications (see Supplemental File S1; https://doi.org/10.3168/jds.2016-11813) were aggregated into an Excel 2010 (Microsoft, Redmond, WA) spreadsheet. The data set included 147 treatments means (i.e., 66 CTL and $81 \mathrm{CAS}$ ).

Throughout this review the following terminology will be used. A publication might contain more than 1 experiment reporting CTL and CAS treatment means; for example, Choung and Chamberlain (1995) compared the effects of graded levels of casein infusion with corresponding levels of either (1) an enzymatic casein hydrolysate in experiment 1 or (2) free AA in experiment 2. A basal treatment (negative CTL) was included in each experiment; therefore, a mean difference could be computed for each casein infusion level. Each mean difference calculation was used as the response variable (outcome) and was termed a study (Table 1). Overall, 5 studies were created from Choung and Chamberlain (1995): study 47, 48, and 49 from experiment 1, and study 50 and 51 from experiment 2 (Table 1 ).

\section{Calculations}

Mean differences and the corresponding sampling variances were computed from the means, $\mathrm{n}$ and standard deviation of CTL and CAS, using the escalc function in the metafor package (Viechtbauer, 2010) for $\mathrm{R}$ (version 3.3.1; R Core Team, 2014). The standard deviation (SD; root mean square error) of CTL and CAS were taken as reported or back-calculated from standard error of the mean [SEM; or standard error (SE)] and $\mathrm{SE}$ of the difference between any 2 means (SED). The SD was reported in Guinard et al. (1994). In the other publications, SD was back-calculated by multiplying $\mathrm{SE}$ by $\sqrt{\mathrm{n}_{\mathrm{CTL}}}$ or $\sqrt{\mathrm{n}_{\mathrm{CAS}}}$ and $\mathrm{SED}$ by $1 / \sqrt{1 / n_{\mathrm{CTL}}+1 / \mathrm{n}_{\mathrm{CAS}}}$, respectively (Steel et al., 1997). The sampling variance of a mean difference $\left(v_{i}\right)$ was calculated as $\mathrm{SD}_{\mathrm{CTL}}^{2} / \mathrm{n}_{\mathrm{CTL}}+\mathrm{SD}_{\mathrm{CAS}}^{2} / \mathrm{n}_{\mathrm{CAS}}$.

Plasma concentrations of group $1 \mathrm{AA}$, group $2 \mathrm{AA}$, and URCY AA were not reported, except for URCY AA in Hanigan et al. (2004). In that publication, SD of URCY AA, Arg, Cit, and Orn were back-calculated from SEM. In addition, SD of URCY AA was calculated by propagation of error (Neter et al., 1988) using the SD of Arg, Cit, and Orn, and assuming no correlation among AA:

$$
\mathrm{SD}_{\mathrm{URCY} \mathrm{AA}}=\left[\left(\mathrm{SD}_{\mathrm{Arg}}\right)^{2}+\left(\mathrm{SD}_{\mathrm{Cit}}\right)^{2}+\left(\mathrm{SD}_{\mathrm{Orn}}\right)^{2}\right]^{0.5} .
$$

In Hanigan et al. (2004), the ratio between the backcalculated $(31.0 \mu M)$ and the propagated SD of URCY AA $(24.9 \mu M)$ was 1.24 , indicating unaccounted correlations among Arg, Cit, and Orn. These correlations are unknown but need to be accounted for, because numerically lower SD estimates increase the precision of effect size estimate and might bias the results. Therefore, the propagated SD for URCY AA was multiplied by 1.24 and a similar approach was used to calculate an adjustment factor to correct propagated SD of group 1 AA (1.32) and group 2 AA (1.72). These adjustment factors were calculated from SEM for plasma concentrations of group $1 \mathrm{AA}$ and group $2 \mathrm{AA}$ (M. Larsen, Department of Animal Science, Aarhus University, Foulum, Denmark, personal communication) and SEM from constituent AA in Larsen et al. (2014, 2015).

In line with Martineau et al. (2016), the difference in MP supply between CAS and CTL (i.e., $\triangle \mathrm{MP}$ ) was used rather than the rate of casein infusion. This variable is the sum of the difference in MP supply between CAS and CTL from the diet plus MP supplied from casein. The supply of MP from the diet was calculated using NRC (2001) as described previously (Martineau et al., 2016). To calculate MP supplied by casein, the $\mathrm{CP}$ concentration in casein was converted into MP, assuming (1) 91.0\% DM and 92.7\% CP (DM basis; NRC, 2001) and (2) 100\% intestinal CP digestibility (Huhtanen and Hristov, 2010). Marginal protein efficiency was not reported in publications but was calculated for each casein infusion treatment in reference to CTL treatment. The escalc function of metafor was used to compute the marginal protein efficiency and its variance in each study. For this purpose, MTPY and SD (in $\mathrm{kg} / \mathrm{d}$ ) of CAS and CTL were divided by $\Delta \mathrm{MP}$ (also in $\mathrm{kg} / \mathrm{d}$ ). Marginal protein efficiency was analyzed in absolute units only.

To allow the analysis in percentage-based units, means and SD of CTL and CAS were multiplied by $100 /\left(\mathrm{CTL}\right.$ mean). To calculate $\Delta \mathrm{NE}_{\mathrm{L}}$, the ME content of casein was assumed to be $5.08 \mathrm{Mcal} / \mathrm{kg}$ of DM (Table 10-7 in NRC, 2001) and $\mathrm{ME}$ was converted into $\mathrm{NE}_{\mathrm{L}}$ using equation $2-11$ in NRC (2001). To homogenize units of measurement for some variables, means and SD were multiplied by a constant (e.g., 10/60.05 to convert urea in $\mathrm{mg} / \mathrm{dL}$ into $\mathrm{m} M$ ). 
Table 1. Hierarchical structure of the studies included in the meta-analysis

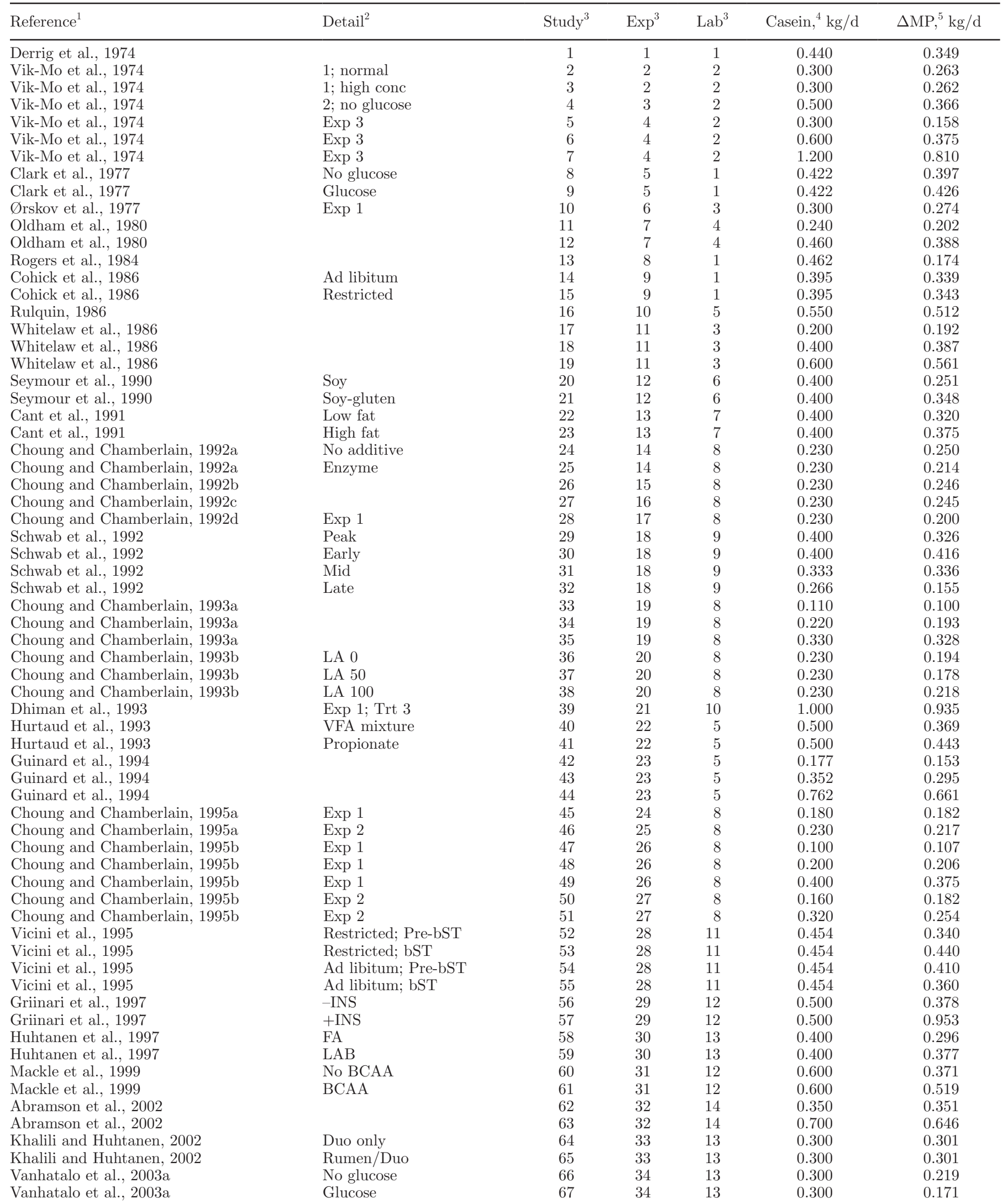


Table 1 (Continued). Hierarchical structure of the studies included in the meta-analysis

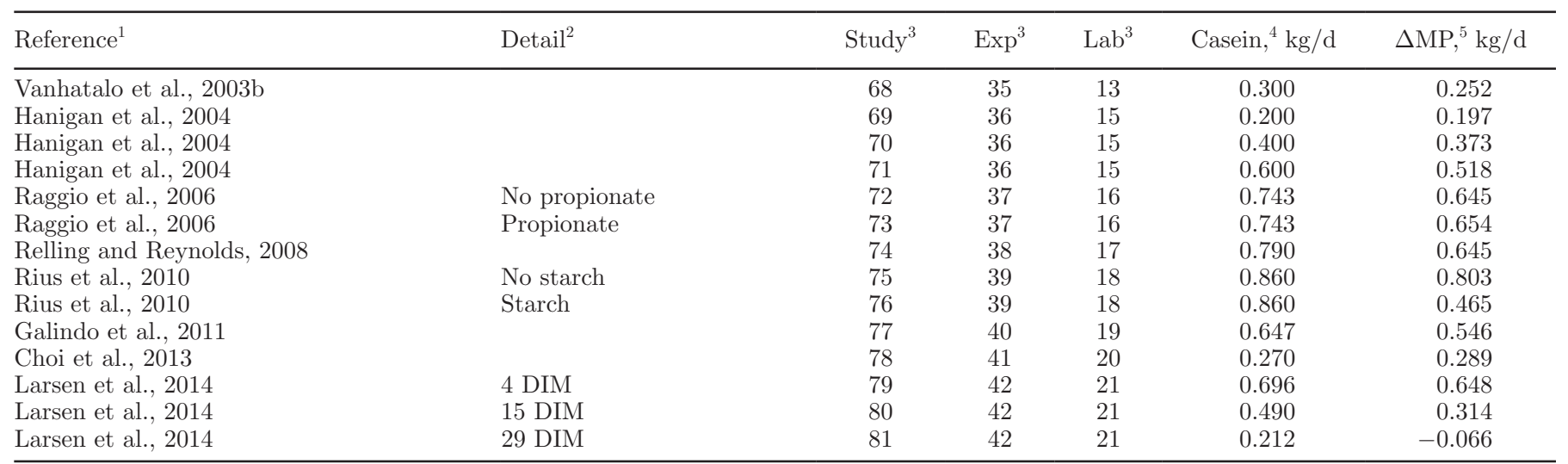

${ }^{1}$ See Supplemental File S1 (https://doi.org/10.3168/jds.2016-11813) for a list of references used in the data set.

${ }^{2}$ Details on the label of the treatment in the original publication. Conc $=$ concentrate; LA = lactic acid; INS = insulin; FA $=$ formic acid; LAB $=$ lactic acid bacteria; $\mathrm{BCAA}=$ branched-chain $\mathrm{AA}$; duo = duodenum; Exp = experiment; Trt = treatment.

${ }^{3}$ Hierarchical structure in the data set: each study includes a casein-infused and a control treatment mean; studies are clustered by experiment (Exp); and Exp are clustered by laboratory (Lab) (refer to the text for more details).

${ }^{4}$ Casein infusion rate, as-is basis.

${ }^{5} \Delta \mathrm{MP}=$ difference in total estimated MP supply (NRC, 2001) between casein-infused and control treatment means.

\section{Hierarchical Structure of the Data and Statistical Model}

The data had a hierarchical structure: studies were nested within experiments, themselves clustered within laboratories (Table 1). Therefore, the data were fitted to a 4-level mixed-effects meta-regression (MR) model to evaluate all relationships taking into account the random variation for observation, study, experiment, and laboratory. All models were fitted with the rma. $m v$ function in metafor (REML method; Viechtbauer, 2016a,b,c), which is used to conduct multilevel metaanalyses that account for the fact that effect sizes are not independent due to the nested structure of the data.

The statistical model including an interaction term can be written as

$$
\begin{gathered}
y_{i j k}=\beta_{0}+\beta_{1} x_{i j k 1}+\beta_{2} x_{i j k 2}+\beta_{3} x_{i j k 1} x_{i j k 2}+u_{i}+w_{i j}+z_{i j k}+e_{i j k}, \\
u_{i} \sim N\left(0, \tau_{\text {study }}^{2}\right), w_{i j} \sim N\left(0, \tau_{\text {experiment }}^{2}\right), \\
z_{i j k} \sim N\left(0, \tau_{\text {laboratory }}^{2}\right), e_{i j k} \sim N\left(0, v_{i j k}\right),
\end{gathered}
$$

where $y_{i j k}$ is the observed outcome for the $i$ th study ( $i$ $\left.=1, \ldots, I_{j k}\right)$, clustered in the $j$ th experiment $(j=1$, $\left.\ldots, J_{k}\right)$ and $k$ th laboratory $(k=1, \ldots, K) ; \beta_{0}, \beta_{1}, \beta_{2}$, and $\beta_{3}$ are, respectively, the fixed effect parameters corresponding to the intercept, the explanatory variables $x_{1}$ and $x_{2}$, and the interaction between $x_{1}$ and $x_{2} ; u_{i}, w_{i j}$, and $z_{i j k}$ are, respectively, random effects for the residual random heterogeneity at the study, experiment, and laboratory levels; and $e_{i j k}$ is the sampling error. The study, experiment, and laboratory random effects are assumed to be independently, identically, and normally distributed with a mean of zero and a variance of $\tau_{\text {study }}^{2}, \tau_{\text {experiment }}^{2}$, and $\tau_{\text {laboratory }}^{2}$, respectively. The sampling errors are assumed to be independently and normally distributed with a mean of zero and a variance of $v_{i j k}$. Therefore, the $v_{i j k}$ are the (approximately) known and heteroscedastic sampling variances of the observed outcomes (W. Viechtbauer, Department of Psychiatry and Neuropsychology, Maastricht University, Maastricht, the Netherlands, personal communication).

\section{Dependent and Explanatory Variables}

The dependent variables were mean differences or responses of milk yield, true protein concentration and yield, fat concentration and yield, lactose concentration and yield, marginal protein efficiency, concentrations in milk and blood urea, and plasma concentrations of individual AA, AA groups, glucose, nonesterified fatty acids (NEFA), and BHB (Table 2).

The explanatory variables are summarized in Table 3 and the correlation coefficients between the explanatory variables are reported in Table 4 . The primary variable of interest was $\Delta \mathrm{MP}$ for the relationships reported in Tables 5, 6, and 7; and $\Delta \mathrm{MP}$ and $\Delta \mathrm{NE}_{\mathrm{L}}$ for relationships reported in Supplemental Tables S1 to S3 (https://doi.org/10.3168/jds.2016-11813).

Other continuous explanatory variables were explored and calculated from CTL treatments to reflect basal levels. All variables were taken as recalculated 
from the nutrient composition of each ration with NRC (2001), as outlined in Martineau et al. (2011, 2016). The variables included (1) estimated MP $(\mathrm{kg} / \mathrm{d})$ and $\mathrm{NE}_{\mathrm{L}}$ (Mcal/d) supplies; (2) balances in MP (kg/d) and $\mathrm{NE}_{\mathrm{L}}$ (Mcal/d); and (3) MCPMP (\%; Table 3). The balances in $\mathrm{MP}$ and $\mathrm{NE}_{\mathrm{L}}$ were the estimated supply minus requirements for maintenance and lactation (NRC, 2001).

Two categorical explanatory variables were tested: stage of lactation and type of forage. Stage of lactation was based on (1) DIM at the initiation of the casein infusion as reported in the publication (early: $\leq 100 \mathrm{~d}$; mid/late: $>100 \mathrm{~d}$ ); (2) stage of lactation as reported in the publication (early: Ørskov et al., 1977; mid/late: Derrig et al., 1974; Abramson et al., 2002; Relling and Reynolds, 2008); and (3) averaged milk yield in the data set (early: $>24.5 \mathrm{~kg} / \mathrm{d}$; mid/late: $\leq 24.5 \mathrm{~kg} / \mathrm{d}$ ). The latter criterion was used for Vik-Mo et al. (1974a,b), Rogers et al. (1984), Rulquin (1986), and Choi et al. (2013). The type of forage fed to cows was categorized as grass/legume-based (grass/legume/mixed hay or silage or straw, but no corn silage) and corn silage-based diets (i.e., diets which included corn silage as the sole or part of the forage DM).

Table 2. Summary statistics for cow-associated variables

\begin{tabular}{|c|c|c|c|c|c|}
\hline Item $^{1}$ & $\mathrm{n}$ & Mean & $\mathrm{SD}$ & Minimum & Maximum \\
\hline DMI, kg/d & 147 & 16.4 & 3.31 & 9.1 & 24.8 \\
\hline \multicolumn{6}{|l|}{ Production variables } \\
\hline Milk yield, $\mathrm{kg} / \mathrm{d}$ & 147 & 24.5 & 7.84 & 10.7 & 48.9 \\
\hline True protein concentration, $\%$ & 147 & 3.08 & 0.288 & 2.46 & 4.28 \\
\hline True protein yield, g/d & 137 & 728 & 221.1 & 318 & 1,580 \\
\hline Fat concentration, $\%$ & 147 & 3.96 & 0.663 & 2.58 & 5.40 \\
\hline Fat yield, g/d & 123 & 961 & 247.4 & 526 & 1,840 \\
\hline Lactose concentration, \% & 99 & 4.70 & 0.181 & 4.35 & 5.28 \\
\hline Lactose yield, g/d & 81 & 1,090 & 386.1 & 499 & 2,370 \\
\hline Marginal protein efficiency, $\mathrm{kg} / \mathrm{kg}$ & 75 & 0.26 & 0.158 & -0.18 & 0.66 \\
\hline \multicolumn{6}{|l|}{ Urea concentration } \\
\hline Milk urea, $\mathrm{m} M$ & 22 & 4.63 & 1.547 & 1.68 & 7.58 \\
\hline Blood urea, $\mathrm{m} M$ & 80 & 5.01 & 2.543 & 1.98 & 15.93 \\
\hline \multicolumn{6}{|l|}{ AA plasma concentration, $\mu M$} \\
\hline Arginine & 87 & 74 & 17.3 & 37 & 127 \\
\hline Citrulline & 32 & 80 & 23.1 & 43 & 129 \\
\hline Ornithine & 32 & 55 & 12.9 & 30 & 82 \\
\hline Urea cycle (URCY) AA & 32 & 211 & 37.4 & 129 & 274 \\
\hline Histidine & 93 & 42 & 14.8 & 9 & 85 \\
\hline Methionine $^{2}$ & 81 & 21 & 5.4 & 8 & 37 \\
\hline Phenylalanine & 93 & 49 & 9.8 & 34 & 94 \\
\hline Tyrosine & 85 & 49 & 10.0 & 25 & 77 \\
\hline Group $1 \mathrm{AA}^{2}$ & 81 & 159 & 26.3 & 96 & 218 \\
\hline Isoleucine & 93 & 106 & 33.0 & 15 & 177 \\
\hline Leucine & 93 & 134 & 49.7 & 60 & 258 \\
\hline Lysine $^{2}$ & 85 & 80 & 21.9 & 20 & 128 \\
\hline Valine & 93 & 226 & 70.7 & 96 & 416 \\
\hline Group $2 \mathrm{AA}^{2}$ & 85 & 540 & 153.3 & 258 & 921 \\
\hline Threonine & 93 & 104 & 23.6 & 54 & 163 \\
\hline Tryptophan & 65 & 40 & 18.0 & 15 & 100 \\
\hline Alanine & 85 & 187 & 33.7 & 86 & 272 \\
\hline Asparagine & 38 & 52 & 20.3 & 28 & 107 \\
\hline Aspartate & 81 & 12 & 15.5 & $<1$ & 86 \\
\hline Glutamine & 50 & 207 & 75.6 & 32 & 429 \\
\hline Glutamate & 85 & 75 & 56.4 & 25 & 304 \\
\hline Glycine & 85 & 309 & 87.9 & 160 & 514 \\
\hline Proline & 48 & 91 & 35.1 & 42 & 195 \\
\hline Serine & 85 & 94 & 16.4 & 62 & 130 \\
\hline \multicolumn{6}{|l|}{ Plasma concentration } \\
\hline Glucose ${ }^{3} \mathrm{~m} M$ & 84 & 3.6 & 0.49 & 2.1 & 4.6 \\
\hline Nonesterified fatty acids, $\mu M$ & 66 & 162 & 112.4 & 20 & 572 \\
\hline $\mathrm{BHB}, \mu M$ & 46 & 919 & 486.4 & 250 & 2,430 \\
\hline
\end{tabular}

${ }^{1}$ Variables are presented in the same order as in Tables 5 to 7 . Marginal protein efficiency $=$ difference in true protein yield $(\mathrm{kg} / \mathrm{d})$ divided by the difference in estimated MP supply (diet plus casein, $\mathrm{kg} / \mathrm{d}$ ). The difference was calculated in each study as casein-infused minus control treatment means. URCY AA = Arg, Cit, and Orn; Group $1 \mathrm{AA}=$ His, Met, and Phe+Tyr; Group $2 \mathrm{AA}=$ Ile, Leu, Lys, and Val.

${ }^{2}$ Data from Schwab et al. (1992) are not included.

${ }^{3}$ Data from Griinari et al. (1997) are not included. 
Table 3. Summary statistics for the explanatory variables ${ }^{1}$

\begin{tabular}{|c|c|c|c|c|c|c|c|}
\hline Item $^{2}$ & $\mathrm{n}^{3}$ & Mean & $\mathrm{SD}$ & Minimum & 1st quartile & 3rd quartile & Maximum \\
\hline$\Delta \mathrm{MP}, \mathrm{kg} / \mathrm{d}$ & 81 & 0.355 & 0.1861 & -0.066 & 0.217 & 0.413 & 0.953 \\
\hline$\Delta \mathrm{NE}_{\mathrm{L}},{ }^{4} \mathrm{Mcal} / \mathrm{d}$ & 81 & 1.21 & 1.248 & -2.33 & 0.57 & 1.72 & 7.72 \\
\hline $\mathrm{MP}_{\mathrm{CN}}: \mathrm{MP}_{\text {TOTAL }}, \%$ & 81 & 18.4 & 7.40 & 6.1 & 13.2 & 20.8 & 46.6 \\
\hline $\mathrm{NE}_{\mathrm{LCN}}: \mathrm{NE}_{\mathrm{LTOTAL}}{ }^{4} \%$ & 81 & 4.5 & 2.60 & 0.6 & 2.7 & 5.1 & 15.3 \\
\hline MP supply, kg/d & 66 & 1.62 & 0.431 & 0.82 & 1.33 & 1.85 & 2.92 \\
\hline $\mathrm{NE}_{\mathrm{L}}$ supply, Mcal/d & 66 & 26.1 & 5.39 & 11.5 & 21.7 & 30.3 & 38.1 \\
\hline MP balance, kg/d & 66 & -0.08 & 0.279 & -0.75 & -0.25 & 0.07 & 0.65 \\
\hline $\mathrm{NE}_{\mathrm{L}}$ balance, Mcal/d & 66 & -0.56 & 3.565 & -8.96 & -2.93 & 1.73 & 7.96 \\
\hline MCPMP, \% & 66 & 54.1 & 7.62 & 35.4 & 48.7 & 58.2 & 69.2 \\
\hline
\end{tabular}

${ }^{1}$ All variables were calculated based on NRC (2001).

${ }^{2} \Delta \mathrm{MP}$ and $\Delta \mathrm{NE}_{\mathrm{L}}=$ within-study differences in estimated $\mathrm{MP}$ and $\mathrm{NE}_{\mathrm{L}}$ supply between casein-infused and control treatment means; $\mathrm{MP}_{\mathrm{CN}}$ and $\mathrm{NE}_{\mathrm{LCN}}=$ estimated $\mathrm{MP}$ and $\mathrm{NE}_{\mathrm{L}}$ supplied by the infusion of casein; $\mathrm{MP}_{\mathrm{TOTAL}}$ and $\mathrm{NE}_{\mathrm{LTOTAL}}=$ total estimated $\mathrm{MP}$ and $\mathrm{NE}_{\mathrm{L}}$ supplied; balance = supply minus requirements for maintenance and lactation; MCPMP = ratio of duodenal microbial protein in the estimated MP supply.

${ }^{3} \mathrm{n}=81$ for variables computed from all studies reported in Table 1 ; and $\mathrm{n}=66$ for variables computed from control treatment means only.

${ }^{4} \mathrm{ME}$ content of casein $=5.08 \mathrm{Mcal} / \mathrm{kg}$ and $\mathrm{NE}_{\mathrm{L}}=[0.703 \times \mathrm{ME}(\mathrm{Mcal} / \mathrm{kg})-0.19](\mathrm{NRC}, 2001)$.

\section{Meta-Regressions}

The explanatory variables were centered to their means to facilitate the interpretation of results and avoid multicollinearity among variables (Kleinbaum et al., 1998). Therefore, the intercept is the dependent variable estimated at the mean value of all the explanatory variables included in the model because the centered explanatory variables will have zero as their overall mean (Kleinbaum et al., 1998). The slope of each explanatory variable is the change in the dependent variable for a 1-unit change in the explanatory variable from its mean (when other explanatory variables in the model are kept at their means).

The effects of casein infusion among studies were evaluated in unconditional (without explanatory variables) and conditional models (with explanatory variables). The relationships between each dependent and independent variable were assessed separately. For each dependent variable, a complete model was built by (1) forcing $\triangle \mathrm{MP}$ in the model; (2) including $\Delta \mathrm{MP}$ $\times \Delta \mathrm{MP} ;(3)$ selecting the explanatory variables related
$(P \leq 0.10)$ to the dependent variable under study; and (3) including the interaction terms between $\Delta \mathrm{MP}$ and the other explanatory variables (with $P \leq 0.10$ ). To avoid multicollinearity, explanatory variables highly correlated with each other ( $\mathrm{r}>0.70$; Table 4) were tested separately. Then, a backward elimination approach was used to obtain a parsimonious model by (1) using the same predictors for relationships quantified using absolute and percentage-based units; (2) forcing $\triangle \mathrm{MP}$ in the model; (3) including an interaction term in the model if its $P$-value was $\leq 0.10$ either for the relationship quantified using absolute or percentage-based units (e.g., MR21; Table 6); (4) including lower order terms for an interaction regardless of their significance (e.g., MR6, Table 5); and (5) including other variables in the model if the estimate of the coefficient of $\Delta \mathrm{MP}$ meaningfully changed when they were removed from the model, as suggested by Kleinbaum et al. (1998). The latter indicates that a subjective decision was required as to whether the estimate of the coefficient of $\Delta \mathrm{MP}$ described a different interpretation of the relationship between the response and $\Delta \mathrm{MP}$ when another variable

Table 4. Correlation coefficients between the explanatory variables ${ }^{1}$

\begin{tabular}{lcccccc}
\hline Item $^{2}$ & \multirow{2}{*}{$\mathrm{NE}_{\mathrm{L}}$} & $\mathrm{MP}$ supply & $\mathrm{NE}_{\mathrm{L}}$ supply & $\mathrm{MP}$ balance & $\mathrm{NE}_{\mathrm{L}}$ balance & $\mathrm{MCPMP}$ \\
\hline$\Delta \mathrm{MP}$ & 0.78 & 0.12 & 0.13 & -0.10 & -0.10 & -0.12 \\
$\Delta \mathrm{NE}_{\mathrm{L}}$ & & -0.07 & -0.09 & -0.12 & -0.19 & -0.04 \\
$\mathrm{MP}$ supply & & & 0.92 & 0.37 & 0.46 & -0.55 \\
$\mathrm{NE}_{\mathrm{L}}$ supply & & & & 0.14 & 0.50 & -0.28 \\
$\mathrm{MP}_{\text {balance }}$ & & & & 0.71 & -0.50 \\
$\mathrm{NE}_{\mathrm{L}}$ balance & & & & & -0.15 \\
\hline
\end{tabular}

${ }^{1}$ Pearson's product-moment correlation; $\mathrm{df}=79$.

${ }^{2} \Delta \mathrm{MP}$ and $\Delta \mathrm{NE}_{\mathrm{L}}=$ within-study differences in estimated $\mathrm{MP}$ and $\mathrm{NE}_{\mathrm{L}}$ supply between casein-infused and control treatment means; balance $=$ supply minus requirements for maintenance and lactation; $\mathrm{MCPMP}=$ ratio of duodenal microbial protein in the estimated MP supply. 
Table 5. Meta-regressions (MR) for the relationships between casein infusion and the responses of production variables, marginal protein efficiency, and concentrations of milk and blood urea and plasma AA from the urea cycle in dairy cows ${ }^{1}$

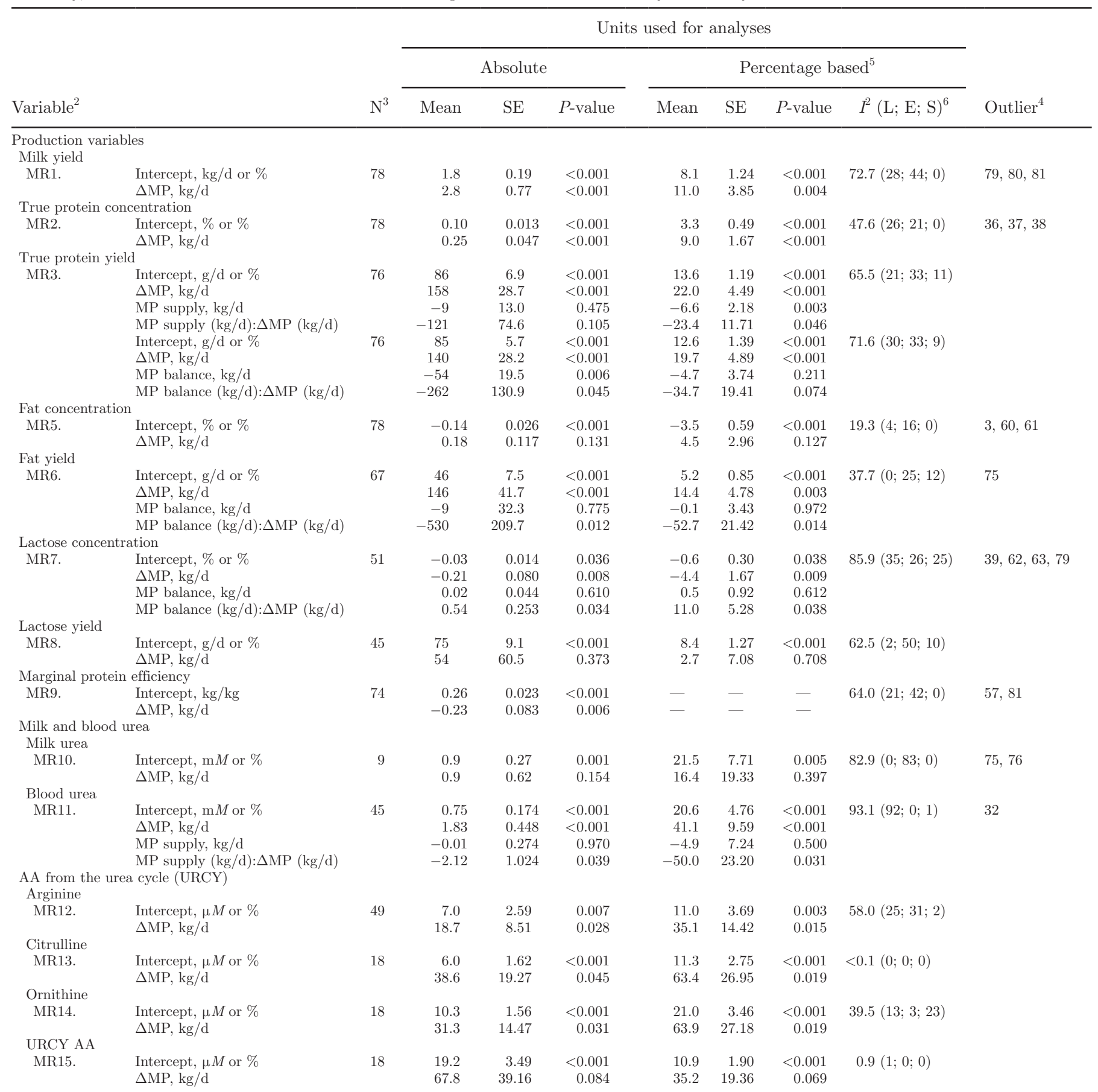

${ }^{1} \mathrm{~A}$ mixed-effects multilevel model was used to test all relationships (refer to the text). Continuous explanatory variables were centered to their mean; therefore, the intercept is the average response to casein infusion at the mean value of the explanatory variables included in the model. All explanatory variables (except $\Delta \mathrm{MP}$ ) were calculated in control (CTL) treatments and based on NRC (2001).

${ }^{2} \Delta \mathrm{MP}=$ difference in total estimated MP supply between casein-infused and CTL treatment means; MP balance $=$ MP supply minus requirements for maintenance and lactation; marginal protein efficiency = within-study difference in true protein yield (kg/d) divided by $\Delta \mathrm{MP}$ (diet plus casein, $\mathrm{kg} / \mathrm{d}$ ); URCY AA = Arg, Cit, and Orn.

${ }^{3}$ Number of studies included in the model; the same studies were used for the analysis based on absolute and percentage-based units.

${ }^{4}$ Outliers not included in the model (refer to Table 1 for the identification number).

${ }^{5}$ Each response was converted to a percentage based on data from the CTL treatment (i.e., the average percentage increase or decrease in casein-infused treatments relative to CTL treatments).

${ }^{6} I^{2}=$ test statistic (\%), which indicates to what extent heterogeneity contributes to the total variance. The percentage of the total variance estimated to be due to the heterogeneity between laboratory (L), experiment $(\mathrm{E})$, and study $(\mathrm{S})$ is reported within parentheses; the remaining (i.e., 100 minus $I^{2}$ ) is due to the sampling variance. 
Table 6. Meta-regressions (MR) for the relationships between casein infusion and the responses of plasma concentrations of AA from group 1 and group 2, Thr, and Trp in dairy cows ${ }^{1}$

\begin{tabular}{|c|c|c|c|c|c|c|c|c|c|c|}
\hline \multirow[b]{3}{*}{ Variable $^{2}$} & & \multirow[b]{3}{*}{$\mathrm{N}^{3}$} & \multicolumn{7}{|c|}{ Units used for analyses } & \multirow[b]{3}{*}{ Outlier ${ }^{4}$} \\
\hline & & & \multicolumn{3}{|c|}{ Absolute } & \multicolumn{4}{|c|}{ Percentage based $^{5}$} & \\
\hline & & & Mean & $\mathrm{SE}$ & $P$-value & Mean & $\mathrm{SE}$ & $P$-value & $I^{2}(\mathrm{~L} ; \mathrm{E} ; \mathrm{S})^{6}$ & \\
\hline \multirow{2}{*}{\multicolumn{11}{|c|}{ AA from group 1}} \\
\hline & & & & & & & & & & \\
\hline \multirow[t]{4}{*}{ MR16. } & Intercept, $\mu M$ or $\%$ & 52 & 13.8 & 1.95 & $<0.001$ & 53.4 & 10.33 & $<0.001$ & $94.5(32 ; 23 ; 40)$ & \\
\hline & $\Delta \mathrm{MP}, \mathrm{kg} / \mathrm{d}$ & & 27.0 & 7.45 & $<0.001$ & 121.2 & 35.97 & $<0.001$ & & \\
\hline & MCPMP, \% & & 0.4 & 0.20 & 0.021 & 3.6 & 1.13 & 0.002 & & \\
\hline & $\operatorname{MCPMP}(\%): \Delta \mathrm{MP}(\mathrm{kg} / \mathrm{d})$ & & 2.4 & 1.07 & 0.027 & 14.5 & 5.66 & 0.010 & & \\
\hline \multirow[t]{4}{*}{ MR17. } & Intercept (grass/legume) ${ }^{7} \mu M$ or $\%$ & 52 & 14.1 & 2.78 & $<0.001$ & 53.1 & 15.46 & $<0.001$ & $95.9(50 ; 18 ; 28)$ & \\
\hline & Intercept (corn), $\mu M$ or $\%$ & & 10.1 & 3.79 & 0.008 & 27.8 & 21.77 & 0.201 & & \\
\hline & Forage (grass/legume): $\Delta \mathrm{MP}(\mathrm{kg} / \mathrm{d})^{7}$ & & 37.3 & 9.53 & $<0.001$ & 157.0 & 46.36 & $<0.001$ & & \\
\hline & Forage $(\operatorname{corn}): \Delta \mathrm{MP}(\mathrm{kg} / \mathrm{d})$ & & 6.4 & 9.40 & 0.499 & 13.2 & 42.69 & 0.757 & & \\
\hline \multicolumn{11}{|c|}{ Methionine } \\
\hline \multirow[t]{2}{*}{ MR18. } & Intercept, $\mu M$ or $\%$ & 46 & 2.6 & 0.54 & $<0.001$ & 13.7 & 3.20 & $<0.001$ & $47.7(31 ; 14 ; 3)$ & \\
\hline & $\Delta \mathrm{MP}, \mathrm{kg} / \mathrm{d}$ & & 7.5 & 2.24 & $<0.001$ & 33.4 & 12.46 & 0.007 & & \\
\hline \multicolumn{11}{|c|}{ Phenylalanine } \\
\hline \multirow[t]{2}{*}{ MR19. } & Intercept, $\mu M$ or $\%$ & 52 & 2.9 & 0.57 & $<0.001$ & 6.2 & 1.28 & $<0.001$ & $17.9(4 ; 0 ; 13)$ & \\
\hline & $\Delta \mathrm{MP}, \mathrm{kg} / \mathrm{d}$ & & 7.9 & 3.14 & 0.012 & 20.5 & 7.45 & 0.006 & & \\
\hline \multicolumn{11}{|l|}{ Tyrosine } \\
\hline \multirow{2}{*}{ MR20. } & Intercept, $\mu M$ or $\%$ & 47 & 7.2 & 1.00 & $<0.001$ & 16.8 & 2.67 & $<0.001$ & $52.1(24 ; 0 ; 28)$ & 57 \\
\hline & $\Delta \mathrm{MP}, \mathrm{kg} / \mathrm{d}$ & & 27.6 & 4.63 & $<0.001$ & 72.5 & 12.72 & $<0.001$ & & \\
\hline \multicolumn{11}{|c|}{ Group $1 \mathrm{AA}$} \\
\hline MR21. & Intercept, $\mu M$ or $\%$ & 46 & 27.4 & 3.28 & $<0.001$ & 19.5 & 2.68 & $<0.001$ & $57.4(32 ; 0 ; 25)$ & \\
\hline & $\Delta \mathrm{MP}, \mathrm{kg} / \mathrm{d}$ & & 78.3 & 15.67 & $<0.001$ & 56.3 & 11.77 & $<0.001$ & & \\
\hline & MCPMP, \% & & 0.4 & 0.34 & 0.243 & 0.4 & 0.27 & 0.165 & & \\
\hline & $\operatorname{MCPMP}(\%): \Delta \mathrm{MP}(\mathrm{kg} / \mathrm{d})$ & & 3.3 & 2.05 & 0.113 & 2.7 & 1.61 & 0.099 & & \\
\hline AA from $g$ & & & & & & & & & & \\
\hline Isoleucine & & & & & & & & & & \\
\hline MR22. & Intercept, $\mu M$ or $\%$ & 51 & 21.5 & 1.84 & $<0.001$ & 23.0 & 2.22 & $<0.001$ & $50.9(0 ; 16 ; 35)$ & 61 \\
\hline & $\Delta \mathrm{MP}, \mathrm{kg} / \mathrm{d}$ & & 44.5 & 10.67 & $<0.001$ & 64.4 & 13.45 & $<0.001$ & & \\
\hline Leucine & & & & & & & & & & \\
\hline MR23. & Intercept, $\mu M$ or $\%$ & 51 & 38.3 & 2.75 & $<0.001$ & 39.1 & 3.21 & $<0.001$ & $69.7(0 ; 25 ; 45)$ & 61 \\
\hline & $\Delta \mathrm{MP}, \mathrm{kg} / \mathrm{d}$ & & 83.3 & 14.90 & $<0.001$ & 91.8 & 17.33 & $<0.001$ & & \\
\hline & MP supply, $\mathrm{kg} / \mathrm{d}$ & & -0.6 & 6.67 & 0.931 & -21.3 & 7.24 & 0.003 & & \\
\hline & MP supply $(\mathrm{kg} / \mathrm{d}): \Delta \mathrm{MP}(\mathrm{kg} / \mathrm{d})$ & & -77.2 & 46.21 & 0.095 & -130.1 & 53.75 & 0.016 & & \\
\hline Lysine & & & & & & & & & & \\
\hline MR24. & Intercept, $\mu M$ or $\%$ & 44 & 17.8 & 2.45 & $<0.001$ & 26.7 & 4.07 & $<0.001$ & $56.7(40 ; 17 ; 0)$ & $57,75,79,81$ \\
\hline & $\Delta \mathrm{MP}, \mathrm{kg} / \mathrm{d}$ & & 58.1 & 12.72 & $<0.001$ & 96.2 & 18.93 & $<0.001$ & & \\
\hline Valine & & & & & & & & & & \\
\hline MR25. & Intercept, $\mu M$ or $\%$ & 51 & 64.6 & 3.46 & $<0.001$ & 37.2 & 2.26 & $<0.001$ & $52.0(0 ; 15 ; 37)$ & 61 \\
\hline & $\Delta \mathrm{MP}, \mathrm{kg} / \mathrm{d}$ & & 140.7 & 21.79 & $<0.001$ & 106.3 & 14.23 & $<0.001$ & & \\
\hline & MP supply, kg/d & & -0.1 & 9.40 & 0.990 & -17.6 & 5.80 & 0.003 & & \\
\hline & MP supply $(\mathrm{kg} / \mathrm{d}): \Delta \mathrm{MP}(\mathrm{kg} / \mathrm{d})$ & & -172.7 & 67.82 & 0.011 & -144.1 & 44.10 & 0.001 & & \\
\hline Group 2 & & & & & & & & & & \\
\hline MR26. & Intercept, $\mu M$ or $\%$ & 47 & 146.3 & 8.57 & $<0.001$ & 33.5 & 2.32 & $<0.001$ & $40.4(0 ; 21 ; 19)$ & 61 \\
\hline & $\Delta \mathrm{MP}, \mathrm{kg} / \mathrm{d}$ & & 329.5 & 50.77 & $<0.001$ & 98.8 & 13.69 & $<0.001$ & & \\
\hline & MP supply, $\mathrm{kg} / \mathrm{d}$ & & 0.1 & 23.55 & 0.999 & -12.6 & 5.69 & 0.027 & & \\
\hline & MP supply $(\mathrm{kg} / \mathrm{d}): \Delta \mathrm{MP}(\mathrm{kg} / \mathrm{d})$ & & -277.4 & 158.37 & 0.080 & -76.6 & 40.90 & 0.061 & & \\
\hline Other EAA & & & & & & & & & & \\
\hline Threonine & & & & & & & & & & \\
\hline MR27. & Intercept, $\mu M$ or $\%$ & 52 & 2.2 & 1.49 & 0.133 & 1.8 & 1.75 & 0.293 & $23.4(23 ; 0 ; 0)$ & \\
\hline & $\Delta \mathrm{MP}, \mathrm{kg} / \mathrm{d}$ & & 20.3 & 7.79 & 0.009 & 22.9 & 9.08 & 0.012 & & \\
\hline Tryptoph & & & & & & & & & & \\
\hline MR28. & Intercept, $\mu M$ or $\%$ & 34 & 0.6 & 0.43 & 0.139 & 1.4 & 1.14 & 0.207 & $15.4(0 ; 15 ; 0)$ & 50,51 \\
\hline & $\Delta \mathrm{MP}, \mathrm{kg} / \mathrm{d}$ & & 3.9 & 1.91 & 0.039 & 7.9 & 4.02 & 0.049 & & \\
\hline
\end{tabular}

${ }^{1}$ A mixed-effects multilevel model was used to test all relationships (refer to the text). Continuous explanatory variables were centered to their mean; therefore, the intercept is the average response to casein infusion at the mean value of the explanatory variables included in the model. All explanatory variables (except $\Delta \mathrm{MP}$ ) were calculated in control (CTL) treatments and based on NRC (2001).

${ }^{2} \Delta \mathrm{MP}=$ difference in total estimated MP supply between casein-infused and CTL treatment means; MCPMP = ratio of duodenal microbial protein in estimated MP supply.

${ }^{3}$ Number of studies included in the model; the same studies were used for the analysis based on absolute and percentage-based units.

${ }^{4}$ Outliers not included in the model (refer to Table 1 for the identification number).

${ }^{5}$ Each response was converted to a percentage based on data from the CTL treatment (i.e., the average percentage increase or decrease in casein-infused treatments relative to CTL treatments).

${ }^{6} I^{2}=$ test statistic (\%), which indicates to what extent heterogeneity contributes to the total variance. The percentage of the total variance estimated to be due to the heterogeneity between laboratory $(\mathrm{L})$, experiment $(\mathrm{E})$ and study $(\mathrm{S})$ is reported within parentheses; the remaining (i.e., 100 minus $\left.I^{2}\right)$ is due to the sampling variance.

${ }^{7}$ Intercepts were not different $(P \geq 0.344 ;$ MR17) but the influence of $\Delta \mathrm{MP}$ on responses in plasma His concentration differed $(P \leq 0.021)$ between grass/legume- and corn silage-based diets. Plasma His concentrations averaged, respectively, $33 \pm 13.8 \mu M$ (range $=9$ to $58 \mu M ; \mathrm{n}=29)$ and $42 \pm 9.7 \mu M$ (range $=27$ to $57 \mu M ; \mathrm{n}=12$ ) for cows fed grass/legume- and corn silage-based diets in CTL treatments. 
Table 7. Meta-regressions (MR) for the relationships between casein infusion and the responses of plasma concentrations of NEAA and other metabolites in dairy cows ${ }^{1}$

\begin{tabular}{|c|c|c|c|c|c|c|c|c|c|c|}
\hline \multirow[b]{3}{*}{ Variable $^{2}$} & & \multirow[b]{3}{*}{$\mathrm{N}^{3}$} & \multicolumn{7}{|c|}{ Units used for analyses } & \multirow[b]{3}{*}{ Outlier ${ }^{4}$} \\
\hline & & & \multicolumn{3}{|c|}{ Absolute } & \multicolumn{4}{|c|}{ Percentage based ${ }^{5}$} & \\
\hline & & & Mean & $\mathrm{SE}$ & $P$-value & Mean & $\mathrm{SE}$ & $P$-value & $I^{2}(\mathrm{~L} ; \mathrm{E} ; \mathrm{S})^{6}$ & \\
\hline \multicolumn{11}{|l|}{ NEAA } \\
\hline \multicolumn{11}{|l|}{ Alanine } \\
\hline \multirow[t]{2}{*}{ MR29. } & Intercept, $\mu M$ or $\%$ & 48 & 3.1 & 4.30 & 0.473 & 1.9 & 2.19 & 0.384 & $60.0(10 ; 47 ; 3)$ & \\
\hline & $\Delta \mathrm{MP}, \mathrm{kg} / \mathrm{d}$ & & 12.1 & 14.49 & 0.404 & 6.6 & 8.27 & 0.423 & & \\
\hline \multicolumn{11}{|c|}{ Asparagine } \\
\hline \multirow[t]{2}{*}{ MR30. } & Intercept, $\mu M$ or $\%$ & 20 & 2.7 & 0.99 & 0.006 & 6.3 & 2.37 & 0.008 & $18.1(8 ; 10 ; 0)$ & 23 \\
\hline & $\Delta \mathrm{MP}, \mathrm{kg} / \mathrm{d}$ & & 5.8 & 4.42 & 0.185 & 13.9 & 9.81 & 0.157 & & \\
\hline \multicolumn{11}{|c|}{ Aspartate } \\
\hline \multirow[t]{2}{*}{ MR31. } & Intercept, $\mu M$ or $\%$ & 44 & 0.1 & 0.21 & 0.574 & 2.4 & 2.87 & 0.403 & $22.5(0 ; 5 ; 18)$ & 43,44 \\
\hline & $\Delta \mathrm{MP}, \mathrm{kg} / \mathrm{d}$ & & 0.7 & 0.93 & 0.453 & 20.7 & 18.23 & 0.256 & & \\
\hline \multicolumn{11}{|c|}{ Glutamate } \\
\hline \multirow[t]{2}{*}{ MR32 } & Intercept, $\mu M$ or $\%$ & 46 & -1.0 & 1.55 & 0.526 & -1.2 & 2.51 & 0.645 & $57.7(45 ; 12 ; 0)$ & 17,19 \\
\hline & $\Delta \mathrm{MP}, \mathrm{kg} / \mathrm{d}$ & & -3.8 & 4.73 & 0.424 & -7.5 & 8.96 & 0.404 & & \\
\hline \multicolumn{11}{|c|}{ Glutamine } \\
\hline \multirow[t]{2}{*}{ MR33. } & Intercept, $\mu M$ or $\%$ & 26 & 0.9 & 11.27 & 0.939 & -0.4 & 6.81 & 0.953 & $87.5(80 ; 7 ; 0)$ & 76 \\
\hline & $\Delta \mathrm{MP}, \mathrm{kg} / \mathrm{d}$ & & 1.7 & 21.43 & 0.937 & 1.3 & 11.12 & 0.905 & & \\
\hline \multicolumn{11}{|l|}{ Glycine } \\
\hline \multirow[t]{4}{*}{ MR34. } & Intercept, $\mu M$ or $\%$ & 45 & -17.8 & 6.20 & 0.004 & -6.4 & 2.04 & 0.002 & $45.3(31 ; 15 ; 0)$ & $19,79,81$ \\
\hline & $\Delta \mathrm{MP}, \mathrm{kg} / \mathrm{d}$ & & -17.9 & 21.46 & 0.404 & -4.8 & 8.37 & 0.565 & & \\
\hline & MP balance, $\mathrm{kg} / \mathrm{d}$ & & -28.4 & 19.62 & 0.147 & -12.3 & 6.53 & 0.059 & & \\
\hline & MP balance $(\mathrm{kg} / \mathrm{d}): \Delta \mathrm{MP}(\mathrm{kg} / \mathrm{d})$ & & 252.0 & 98.98 & 0.011 & 84.8 & 40.13 & 0.035 & & \\
\hline MR35. & Intercept (early), ${ }^{7} \mu M$ or $\%$ & 45 & -19.9 & 9.49 & 0.036 & -6.5 & 2.99 & 0.031 & $36.2(7 ; 29 ; 0)$ & $19,79,81$ \\
\hline & Intercept (mid/late), $\mu M$ or $\%$ & & -17.3 & 5.81 & 0.003 & -6.5 & 1.92 & $<0.001$ & & \\
\hline & Stage (early): $\Delta \mathrm{MP}(\mathrm{kg} / \mathrm{d})^{7}$ & & -117.5 & 49.36 & 0.017 & -35.7 & 16.04 & 0.026 & & \\
\hline & Stage (mid/late): $\Delta \mathrm{MP}(\mathrm{kg} / \mathrm{d})$ & & 5.2 & 22.09 & 0.814 & 0.3 & 8.36 & 0.972 & & \\
\hline Proline & & & & & & & & & & \\
\hline MR36. & Intercept, $\mu M$ or $\%$ & 27 & 40.4 & 6.67 & $<0.001$ & 63.4 & 12.74 & $<0.001$ & $89.3(80 ; 0 ; 9)$ & \\
\hline & $\Delta \mathrm{MP}, \mathrm{kg} / \mathrm{d}$ & & 52.7 & 18.20 & 0.004 & 67.0 & 23.66 & 0.005 & & \\
\hline Serine & & & & & & & & & & \\
\hline MR37. & Intercept, $\mu M$ or $\%$ & 46 & 2.6 & 2.50 & 0.290 & 3.6 & 3.04 & 0.236 & $67.5(60 ; 0 ; 8)$ & 44,57 \\
\hline & $\Delta \mathrm{MP}, \mathrm{kg} / \mathrm{d}$ & & 13.1 & 10.12 & 0.196 & 17.9 & 12.43 & 0.151 & & \\
\hline & MP balance, $\mathrm{kg} / \mathrm{d}$ & & 1.1 & 9.95 & 0.915 & 1.1 & 11.15 & 0.921 & & \\
\hline & MP balance $(\mathrm{kg} / \mathrm{d}): \Delta \mathrm{MP}(\mathrm{kg} / \mathrm{d})$ & & 83.9 & 51.51 & 0.103 & 107.4 & 54.49 & 0.049 & & \\
\hline MR38. & Intercept (early), ${ }^{8} \mu M$ or $\%$ & 46 & 0.6 & 4.55 & 0.901 & 0.4 & 4.81 & 0.935 & $60.0(53 ; 0 ; 7)$ & 44,57 \\
\hline & Intercept (mid/late), $\mu M$ or $\%$ & & 4.2 & 2.47 & 0.086 & 5.9 & 3.06 & 0.054 & & \\
\hline & Stage (early): $\Delta \mathrm{MP}(\mathrm{kg} / \mathrm{d})^{8}$ & & -10.4 & 17.32 & 0.550 & -13.5 & 18.20 & 0.457 & & \\
\hline & Stage (mid/late): $\Delta \mathrm{MP}(\mathrm{kg} / \mathrm{d})$ & & 28.1 & 11.52 & 0.015 & 38.2 & 15.14 & 0.012 & & \\
\hline Other met & ites & & & & & & & & & \\
\hline Glucose & & & & & & & & & & \\
\hline MR39. & Intercept, $\mathrm{m} M$ or $\%$ & 48 & 0.05 & 0.021 & 0.027 & 1.3 & 0.62 & 0.034 & $51.6(0 ; 40 ; 12)$ & \\
\hline & $\Delta \mathrm{MP}, \mathrm{kg} / \mathrm{d}$ & & 0.04 & 0.065 & 0.548 & 1.0 & 1.80 & 0.592 & & \\
\hline NEFA & & & & & & & & & & \\
\hline MR40. & Intercept, $\mu M$ or $\%$ & 37 & 6.5 & 4.03 & 0.105 & 5.1 & 3.20 & 0.115 & $29.2(29 ; 0 ; 0)$ & \\
\hline & $\Delta \mathrm{MP}, \mathrm{kg} / \mathrm{d}$ & & -26.1 & 15.52 & 0.092 & -20.9 & 13.88 & 0.132 & & \\
\hline BHB & & & & & & & & & & \\
\hline MR41. & Intercept, $\mu M$ or $\%$ & 24 & -13.0 & 18.81 & 0.489 & -1.4 & 2.81 & 0.627 & $70.1(14 ; 8 ; 48)$ & $79,80,81$ \\
\hline & $\Delta \mathrm{MP}, \mathrm{kg} / \mathrm{d}$ & & 8.3 & 124.45 & 0.947 & -1.8 & 15.58 & 0.910 & & \\
\hline
\end{tabular}

${ }^{1} \mathrm{~A}$ mixed-effects multilevel model was used to test all relationships (refer to the text). Continuous explanatory variables were centered to their mean; therefore, the intercept is the average response to casein infusion at the mean value of the explanatory variables included in the model. All explanatory variables (except $\Delta$ MP) were calculated in control (CTL) treatments and based on NRC (2001).

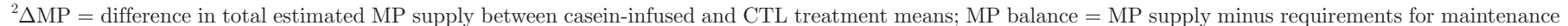
and lactation; NEFA = nonesterified fatty acids.

${ }^{3}$ Number of studies included in the model; the same studies were used for the analysis based on absolute and percentage-based units.

${ }^{4}$ Outliers not included in the model (refer to Table 1 for the identification number).

${ }^{5}$ Each response was converted to a percentage based on data from the CTL treatment (i.e., the average percentage increase or decrease in casein-infused treatments relative to CTL treatments).

${ }^{6} I^{2}=$ test statistic (\%), which indicates to what extent heterogeneity contributes to the total variance. The percentage of the total variance estimated to be due to the heterogeneity between laboratory (L), experiment $(\mathrm{E})$, and study (S) is reported within parentheses; the remaining (i.e., 100 minus $I^{2}$ ) is due to the sampling variance.

${ }^{7}$ Intercepts were not different $(P \geq 0.814 ;$ MR35) and the influence of $\Delta \mathrm{MP}$ on responses in plasma Gly concentration differed $(P \leq 0.046)$ between early and mid/ late lactation. Plasma Gly concentrations averaged, respectively, $348 \pm 65.4 \mu M$ (range $=281$ to $486 \mu M ; \mathrm{n}=9$ ) and $300 \pm 82.8 \mu M$ (range $=178$ to $472 \mu M ; \mathrm{n}=$ 26) for CTL cows in early and mid/late lactation.

${ }^{8}$ Intercepts were not different $(P \geq 0.303 ;$ MR38) and the influence of $\Delta \mathrm{MP}$ on responses in plasma Ser concentration tended $(P \leq 0.063)$ to differ between early and mid/late lactation. Plasma Ser concentrations averaged, respectively, $113 \pm 14.4 \mu M$ (range $=91$ to $130 \mu M ; \mathrm{n}=11$ ) and $87 \pm 16.1 \mu M$ (range $=62$ to 118 $\mu M ; \mathrm{n}=25)$ for CTL cows in early and mid/late lactation. 
was included or not in the model. A statistical test is neither required nor appropriate to make the decision (Kleinbaum et al., 1998).

A test for the residual heterogeneity is printed in the rma.mv function output for unconditional and conditional models (i.e., $Q$ and $Q_{E}$ statistics, respectively); the higher the value, the greater the heterogeneity in true effects. A significant test statistic indicates that the variability in the observed outcomes that is not accounted for by the explanatory variables in the model (unexplained variation) is larger than one would expect based on the sampling variability (and the given covariances among the sampling errors) alone (Viechtbauer, 2016a). The $Q_{E}$ statistic is not reported in Table 5 to 7 , but was replaced by the $I^{2}$ statistic, which estimates the amount of heterogeneity relative to the total amount of variance in the observed outcomes (Higgins and Thompson, 2002). The total variance is composed of the variance in the true effects plus the sampling variance. Although not printed in the rma.mv function output, the $I^{2}$ statistic was computed because it has become a rather popular statistic to report in meta-analyses and easier to interpret than $Q$ and $Q_{E}$ statistics. The $I^{2}$ statistic was computed as (Viechtbauer, 2016d)

$$
I^{2}=100 \% \times \frac{\hat{\tau}^{2}}{\hat{\tau}^{2}+\frac{k-p}{\operatorname{tr}[\mathbf{P}]},}
$$

where $\hat{\tau}^{2}$ is the estimated value of the variance in the true effects $\left(\tau^{2}\right), k$ is the number of study, $p=$ the number of columns in $\mathbf{X}, \operatorname{tr}[\mathbf{P}]=$ the trace of the $\mathbf{P}$ matrix (i.e., the sum of the diagonal elements). The $\mathbf{P}$ matrix was computed as

$$
\mathbf{P}=\mathbf{W}-\mathbf{W X}\left(\mathbf{X}^{\prime} \mathbf{W} \mathbf{X}\right)^{-1} \mathbf{X}^{\prime} \mathbf{W}
$$

where $\mathbf{W}$ is a diagonal matrix with the inverse sampling variances (i.e., $1 / v_{i}$ ) along the diagonal and $\mathbf{X}$ is the model matrix. The $I^{2}$ statistic was further broken down to estimate how much of the total variance can be attributed to between- and within-cluster heterogeneity separately, rather than chance (Viechtbauer, 2016d).

All models included a weight matrix, which was the inverse of the marginal variance-covariance matrix (Viechtbauer, 2016a). Note that the inclusion of different explanatory variables changes the estimates of variance components and modifies the weight matrix. Therefore, the weight matrix will vary from one MR to the other for the same dependent variable (W. Viechtbauer, Department of Psychiatry and Neuropsychology,
Maastricht University, Maastricht, the Netherlands, personal communication).

\section{Diagnostic Tests}

Forest plots were created using the forest function in the metafor package. Forest plots are useful to detect de facto specific patterns among studies, large mean differences, or confidence intervals suggesting the presence of outliers or errors made during data aggregation. Mean differences in percentage-based units were plotted against CTL means in absolute units to detect disproportionate mean difference percentages associated with small CTL means. A graphical assessment of all relationships was carried out using the ggplot function of the ggplot2 package for R (Wickham, 2009), and each data point was graphed against the inverse of its variance to reveal potential outliers and studies with extraneous statistical weight.

Other diagnostic tools included functions to reveal (1) the profile likelihood plots of the variance components of the model (profile.rma.mv); (2) various aspects and assumptions of the data [e.g., normal distribution, enough moderators in the model, publication bias (qqnorm)]; (3) potential data entry error by plotting standardized residuals (rstandard) against the fitted values (fitted); (4) influential observations in the regression coefficients by plotting Cook's distance values (cooks.distance.rma.mv) against the observation number; (5) the occurrence of a publication bias (funnel); and (6) the cluster-robust inference (robust). Relevant $\mathrm{R}$ codes are given in Supplemental File S2 (https://doi. org/10.3168/jds.2016-11813).

Probabilities $\leq 0.05$ will be referred to as significant and probabilities of $0.05<P \leq 0.10$ will be referred to as a tendency in the text. This research project received the approval from the Animal Care and Use Committee from the Sherbrooke Research Centre.

\section{RESULTS AND DISCUSSION}

\section{Features of the Data Set}

The data set included 23 experiments from northern European countries, 17 from North America, and 1 each from Israel (Abramson et al., 2002) and South Korea (Choi et al., 2013; Table 1). All-forage diets were fed in Dhiman et al. (1993) and Khalili and Huhtanen (2002). The concentrate did not include a protein source in Abramson et al. (2002), Choung and Chamberlain (1993a), Dhiman et al. (1993), Huhtanen et al. (1997), Khalili and Huhtanen (2002), and Ørskov et al. (1977). The data set included, respectively, 29 and 13 experi- 
ments for cows fed grass/legume- and corn silage-based diets. Grass/legume-based diets did not contain corn silage as a feed ingredient, but corn silage-based diets could contain grass/legume hay and silage. The proportions of grass/legume hay and silage in the ration DM averaged $0.6 \pm 0.16$ (range $=0.3$ and 1.0) and $0.2 \pm$ 0.09 (range $=0.0$ and 0.3 ) for grass/legume- and corn silage-based diets, respectively. The infusion of casein was tested on cows in early and mid/late lactation in Schwab et al. (1992); therefore, the data set included 14 and 29 experiments for cows in early and mid/late lactation, respectively.

Graded levels of casein were infused in 9 experiments (Table 1). A single laboratory (Hannah Research Institute, Ayr, UK) provided 31 treatment means, and an additional 4 laboratories contributed $\geq 10$ treatment means each (Table 1). Overall, 57 studies consisted of a single CTL paired to a single CAS and 24 studies had multiple CAS paired to the same CTL: 3 graded levels of casein infusion in 3 experiments (e.g., Abramson et al., 2002) and 4 graded levels of casein infusion in 6 experiments (e.g., Hanigan et al., 2004). As such, the hierarchical structure of the data set warranted the use of a 4-level error structure.

The rate of casein infusion was highly correlated with $\Delta \mathrm{MP}(\mathrm{r}=0.87$; data not shown $)$. In the regression of $\triangle \mathrm{MP}$ against casein infusion rate (DM basis), standardized residuals were $>2.0$ in 4 studies due to large differences in DMI (study 57, 76 and 81) and in diet composition between CAS and CTL treatments (study 13; Table 1). In Rogers et al. (1984), the CTL treatment included a mixture of cottonseed meal and soybean meal ( $55 \mathrm{~g}$ of $\mathrm{N}$ total), but not the CAS treatment.

Some variables were reported less frequently (e.g., concentrations of milk urea and plasma Asn, Cit, and Orn; Table 2); therefore, results should be interpreted cautiously. Overall, the data covered a wide range of feeding and animal conditions (Table 3 ).

\section{Statistical Model and Meta-Regressions}

As mentioned above, a multilevel model was required to take into account the hierarchical structure of the data (Konstantopoulos, 2011). Such a model is applicable when multiple effect size estimates are nested within a higher-level grouping variable (e.g., animals receiving graded levels of casein infusion within a single experiment, multiple experiments from the same laboratory or research institute).

The global effect size was estimated by pooling the effect sizes of each study using the unconditional model. The global effect size indicates the effect (significance and magnitude) of casein infusion on the dependent variable among the studies included in the data set. As such, the global effect size can be compared with results from previous reviews. As pointed out in the introduction, one objective was to explore the influence of explanatory variables (especially $\Delta \mathrm{MP} \approx$ casein infusion rate) on the relationships using conditional models. The explanatory variables were centered to their means; therefore, the intercept could be compared directly to the global effect size because centered explanatory variables will have a zero value at their overall mean (Kleinbaum et al., 1998). Unless specified, the intercept and the global effect size were similar; thus, the unconditional models will not be reported and the intercept will be given the same interpretation as the global effect size.

Results from the conditional models will be discussed in 2 steps: (1) the overall effect of casein infusion on the dependent variable (i.e., magnitude and significance of the intercept) and (2) the relationship between $\Delta \mathrm{MP}$ and the dependent variable (i.e., magnitude and significance of the slope) and the influence of other explanatory variables on this relationship.

Meta-regressions are sequentially numbered in Tables 5 to 7 , and will be referred to by the MR number throughout the text. In some MR, the interaction term was significant for the relationship quantified using percentage-based units but the interaction term tended to be significant (e.g., MR23) or was nonsignificant (NS; e.g., MR3) when the relationship was quantified using absolute units. In MR3, the interaction term indicates that the relationship between $\Delta \mathrm{MP}$ and the response of MTPY differed at every one of the infinite values of MP supply. The negative interaction term in MR3 implies that the greater the MP supply, the smaller the relationship between $\triangle \mathrm{MP}$ and the response of MTPY. One way to quantify this interaction is to calculate the relationships between $\triangle \mathrm{MP}$ and the response of MTPY for MP supply (centered values) at the first quartile, mean, and third quartile, respectively. Note that MP supply averaged $1.33,1.62$, and $1.85 \mathrm{~kg} / \mathrm{d}$ at 1 st quartile, mean and third quartile, respectively; therefore, the corresponding centered MP supply values would average $-0.29,0.00$, and $0.23 \mathrm{~kg} / \mathrm{d}$, respectively (Table $3)$.

The analysis in percentage-based units was used to assess the relative effect of casein infusion among dependent variables with a large difference in absolute unit. For example, the ratio of group $2 \mathrm{AA}$ to group $1 \mathrm{AA}$ intercept was 5.3 and 1.7, respectively, when relationships were quantified using absolute and percentagebased units (at mean of variables in MR26 and MR21, respectively, because centered variables will have zero 
as their overall mean; Kleinbaum et al., 1998). Additionally, the level of significance could vary depending on units used for analyses (e.g., MR3). Unless specified, only the relationships quantified using percentage-based units will be discussed in the text, and those analyzed using absolute units will be reported in the tables for comparison purposes.

The $I^{2}$ statistic estimates the percentage of the unaccounted variance due to residual heterogeneity; the remaining (i.e., $100 \%$ minus $I^{2}$ ) are sampling variance (Viechtbauer, 2016d). Breaking down $I^{2}$ on a betweenand within-cluster basis is appealing when using a multilevel model because it readily identifies the main source of residual heterogeneity. Note that an $I^{2} \approx 0 \%$ indicates that all variability in effect estimates is due to sampling error within studies, and that none is due to heterogeneity. On the other hand, $I^{2}>50 \%$ may reflect notable heterogeneity in the meta-analysis (Higgins and Thompson, 2002).

\section{$\triangle M P$ or $\triangle N E_{L}$ as Primary Explanatory Variables}

As expected, $\Delta \mathrm{MP}$ and $\Delta \mathrm{NE}_{\mathrm{L}}$ were highly correlated $(\mathrm{r}=0.78$; Table 4$)$ and were tested separately because of multicollinearity issues. One can argue that $\Delta \mathrm{NE}_{\mathrm{L}}$ should replace $\Delta \mathrm{MP}$ as the primary explanatory variable because casein is not solely a source of protein, but also a source of energy. In Huhtanen and Hristov (2009), the model predicting milk protein yield based on TDN intake had a slightly lower Akaike information criterion than the model based on the estimated MP supply. This suggests that the supply of energy nutrients is a better predictor of milk protein yield than the supply of MP (Huhtanen and Hristov, 2010). On the other hand, previous research demonstrated that MTPY responses are related more to the infusion of MP than to the infusion of an energy substrate either ruminally (Hurtaud et al., 1993; Vanhatalo et al., 2003b; Raggio et al., 2006; Lemosquet et al., 2009) or postruminally (Clark et al., 1977; Vanhatalo et al., 2003a).

In addition, the relative input of $\mathrm{MP}$ and $\mathrm{NE}_{\mathrm{L}}$ from casein infusion was 4 times greater on total MP supply than on total $\mathrm{NE}_{\mathrm{L}}$ supply in our data set: $18.4 \%$ for mean $\mathrm{MP}_{\mathrm{CN}}: \mathrm{MP}_{\text {TOTAL }}$ versus $4.5 \%$ for mean $\mathrm{NE}_{\mathrm{LCN}}: \mathrm{NE}_{\mathrm{LTOTAL}}$ (Table 3). This suggests that the relationships between casein infusion and the dependent variables could be driven more strongly by differences in MP supply than by differences in $\mathrm{NE}_{\mathrm{L}}$ supply. Nonetheless, all relationships were evaluated using either $\Delta \mathrm{MP}$ or $\Delta \mathrm{NE}_{\mathrm{L}}$ as the primary explanatory variable and results were similar based on Akaike information criterion [see Supplemental Tables S1 to S3 (https://doi.org/10.3168/jds.2016$11813)$ for results using $\Delta \mathrm{MP}$ or $\Delta \mathrm{NE}_{\mathrm{L}}$ as the primary explanatory variable].

\section{Relationships Between Casein Infusion and Responses of Production Variables}

The relationships pertaining to production variables are reported in Table 5. The infusion of casein had a positive effect $(P<0.001)$ on responses of milk and component yields ( $\geq 5 \%$, MR1, MR3, MR4, MR6, and MR8) and of true protein concentration (3\%, MR2). On the other hand, the effect was negative $(P \leq 0.04)$ on responses of fat and lactose concentrations among casein infusion studies (MR5 and MR7, respectively). The effect was highest on the response of MTPY $(14 \%$, MR3), likely due to the combined positive effect on responses of milk yield and true protein concentration, in agreement with Clark (1975). In addition to providing the building blocks for protein synthesis, AA stimulated milk protein synthesis in bovine mammary epithelial cells cultured under lactogenic conditions via regulation of the mammalian target of rapamycin signaling pathway (Moshel et al., 2006; Arriola Apelo et al., 2014).

The relationships between $\Delta \mathrm{MP}$ and responses of milk fat concentration (MR5) and milk lactose yield (MR8) were NS. In contrast, the relationships were significant $(P<0.01)$ between $\Delta \mathrm{MP}$ and responses of milk yield and true protein concentration. For each unit $(\mathrm{kg} / \mathrm{d})$ increment in $\Delta \mathrm{MP}$ from its mean, responses of milk yield and true protein concentration increased, on average, by 11 (MR1) and 9\% (MR2), respectively.

The relationship between $\Delta \mathrm{MP}$ and the response of MTPY was influenced negatively by MP supply $(P=$ $0.05)$ and MP balance $(P=0.07)$. For each unit $(\mathrm{kg} / \mathrm{d})$ increment in $\triangle \mathrm{MP}$ from its mean, responses of MTPY increased, on average, by 29,22 , and $17 \%$ for MP supply at the first quartile, mean, and third quartile, respectively (MR3); and by 25,20 , and $15 \%$ for MP balance at the first quartile, mean, and third quartile, respectively (MR4). Based on the effect size estimates, the response of MTPY is expected to be negative at MP supply $>0.94 \mathrm{~kg} / \mathrm{d}$ or MP balance $>0.57 \mathrm{~kg} / \mathrm{d}$ (centered values). However, more research in this area would enhance our confidence in MR3, because currently only 12 CTL treatments had a MP supply greater than 2.0 $\mathrm{kg} / \mathrm{d}$ in the data set (2 CTL treatments over $2.6 \mathrm{~kg}$ of MP per day; data not shown).

The balance in MP influenced negatively $(P=0.01$, MR6) the relationship between $\triangle \mathrm{MP}$ and the response of fat yield, and positively ( $P=0.04, \mathrm{MR} 7)$ influenced that for the response of lactose concentration. Based on effect size estimates, the response of fat yield is expected to be negative at MP balance $>0.27 \mathrm{~kg} / \mathrm{d}$ (centered values). On the other hand, the response of lactose concentration is expected to be positive at MP balance $>0.40 \mathrm{~kg} / \mathrm{d}$ (centered values). 


\section{Relationship Between Casein Infusion and Marginal Protein Efficiency}

The relationship between casein infusion and marginal protein efficiency was quantified using absolute units only (MR9; Table 5). Marginal protein efficiency averaged $0.26 \pm 0.023(P<0.001)$, in line with Hanigan et al. (1998; 0.24) and Aikman et al. (2002; 0.31). Marginal protein efficiency was related negatively $(P$ $<0.01)$ to $\Delta \mathrm{MP}$, at $-0.23 \mathrm{~kg} / \mathrm{kg}$ per unit $(1 \mathrm{~kg} / \mathrm{d})$ increment in $\triangle \mathrm{MP}$ from its mean. Data from 13 publications were reviewed by Aikman et al. (2002) and the regression of the recovery of casein protein as increased milk protein yield against casein infusion rate had a slope of $-0.57(P<0.001)$. Aikman et al. (2002) hypothesized that lower recoveries at higher casein infusion rates could result from different partitioning of absorbed AA toward protein accretion in body tissues, glucose synthesis, oxidation, and other metabolic functions. In our data set, $\mathrm{N}$ retention or changes in BW were reported in 8 and 3 publications, respectively; thus, the anabolic use of absorbed $\mathrm{N}$ for protein accretion could not be accurately evaluated. However, data from Whitelaw et al. (1986) indicated that the relationship between marginal $\mathrm{N}$ efficiency and casein infusion rate would not be negative if $\mathrm{N}$ retained was added to milk N. In Whitelaw et al. (1986), marginal N efficiencies computed as $[(\Delta$ milk $\mathrm{N}) /(\Delta$ total $\mathrm{N}$ intake, diet + infused casein)] decreased as casein infusion rate increased, with $0.47,0.38$, and $0.30 \mathrm{~kg} / \mathrm{kg}$ for 200,400 , and $600 \mathrm{~g}$ of casein/d, respectively. For comparison purposes, the corresponding marginal $\mathrm{N}$ efficiencies would be $0.69,0.75$, and $0.63 \mathrm{~kg} / \mathrm{kg}$, respectively, if retained $\mathrm{N}$ was added to milk $\mathrm{N}$. On the other hand, liver removal of group $1 \mathrm{AA}$ seems to be related to plasma AA concentrations (Hanigan, 2005; Lapierre et al., 2005), which would indicate increased AA catabolism when increased MP supply elevates plasma AA concentrations, as observed under casein infusion in the current study (see below).

\section{Casein Infusion and Responses of Milk and Blood Urea and Plasma URCY AA Concentrations}

The relationships between casein infusion and responses of milk and blood urea and plasma URCY AA concentrations are reported in Table 5 . The infusion of casein had a positive effect $(P<0.01)$ on responses of milk and blood urea concentrations (MR10 and MR11, respectively), and plasma Arg, Cit, Orn, and URCY AA concentrations (MR12 to MR15). Few publications reported the effect of casein infusion on milk urea and plasma Orn concentrations, but the effect was significant in most of them (data not shown).
The relationship between $\Delta \mathrm{MP}$ and the response of milk urea concentration was NS, probably because few data were available. The supply in MP influenced negatively $(P=0.03)$ the relationship between $\Delta \mathrm{MP}$ and the response of blood urea concentration. For each unit $(\mathrm{kg} / \mathrm{d})$ increment in $\triangle \mathrm{MP}$ from its mean, responses of blood urea concentration increased, on average, by 56 , 41 , and $30 \%$ for MP supply at the first quartile, mean, and third quartile, respectively (MR11). This observation is counterintuitive, because one would expect that casein infused at high basal MP supply could lead to a greater excess in MP supply and urea synthesis versus casein infused at low basal MP supply. In our data set, large responses of blood urea concentration were observed in experiments with low basal MP supply [e.g., Vik-Mo et al. (1974b), Oldham et al. (1980), and Abramson et al. (2002)].

The relationships between $\triangle \mathrm{MP}$ and responses of plasma Arg, Cit, Orn, and URCY AA concentrations were all positive and high despite the fact that Orn and Cit are not directly supplied by casein $(\geq 35 \%, P$ $\leq 0.07$, MR12 to MR15). These results, taken together with those on marginal protein efficiency (MR9), support the concept that a larger proportion of the AA infused were catabolized and contributed to urea synthesis as $\triangle \mathrm{MP}$ increased under casein infusion.

\section{Casein Infusion and Responses of Plasma Group 1 AA, Group 2 AA, Thr, and Trp Concentrations}

The relationships between casein infusion and responses of plasma group 1 AA, group 2 AA, Thr, and Trp concentrations are reported in Table 6. Group 1 AA (His, Met, and Phe+Tyr) represents AA removed by the liver in substantial proportion of their net portal appearance, and for which the postliver supply is almost equal to the mammary uptake (itself equivalent to milk protein secretion). On the other hand, group 2 AA (Ile, Leu, Lys, and Val) represents AA barely extracted by the liver, and for which the postliver supply exceeds the mammary uptake (itself larger than the milk protein output; Lapierre et al., 2012). The infusion of casein had a positive effect $(P<0.001)$ on responses of plasma concentrations of Tyr and all EAA, except on that of Thr and Trp, for which the effect was NS. The latter observation means that the data set included similar proportions of positive and negative responses for these 2 EAA. In addition, the $I^{2}$ statistic in MR27 and MR28 indicated that the contribution of heterogeneity to the total variance present in the data set was small $(\leq 23.4 \%)$ for these 2 AA, taking into account the hierarchical structure of data (Viechtbauer, 2016d). This small $I^{2}$ statistic means that a large part $(>76.6 \%)$ of the variability in effect estimates was due 


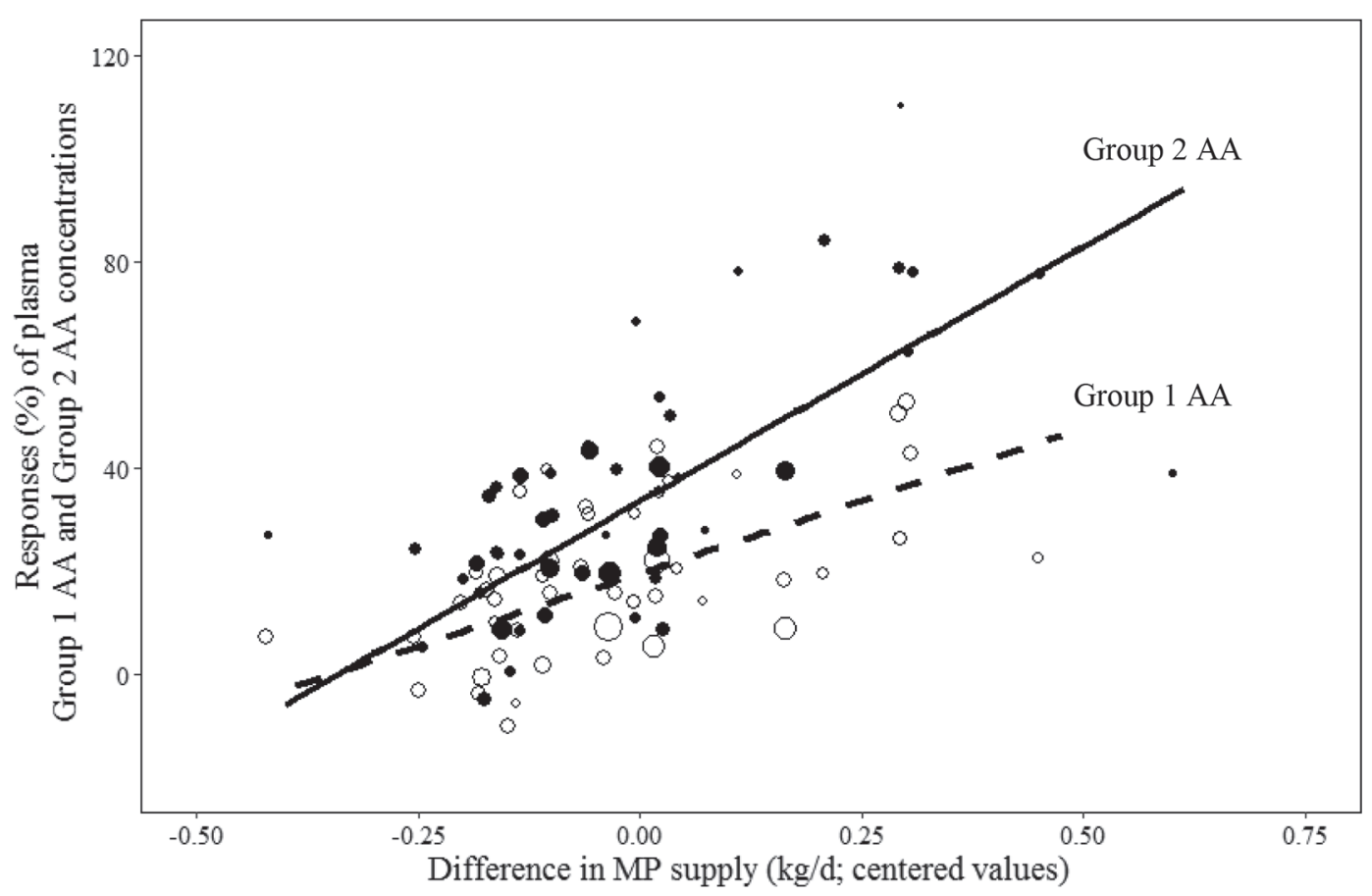

Figure 1. Relationships between responses of plasma group 1 AA (His, Met, and Phe+Tyr; open circles and dashed line) and group 2 AA (Ile, Leu, Lys, and Val; closed circles and straight line) concentrations versus the difference in MP supply between casein-infused and control treatment means $(\mathrm{kg} / \mathrm{d}$; centered values). Relationships were quantified using percentage-based units (at mean of covariates in MR21 and MR26, Table 6). Each data point is drawn proportional to the inverse of variance.

to sampling error within studies (Higgins and Thompson, 2002). This might be related to the conventional AA analytical method; Thr is often difficult to separate from Ser (Lapierre et al., 2012), whereas Trp represents only a small peak at the end of the chromatogram of the AA analysis. The effect was highest for responses of His (53\%, MR16 and MR17), and lowest for responses of Phe $(6 \%$, MR19). We could not find a biological explanation for the small effect on responses of Phe, but results are in line with the small slope between plasma Phe concentration and duodenal Phe flow reported in Patton et al. (2015).

At the mean of covariables in each model, our results indicate that $\triangle \mathrm{MP}$ was related positively $(P \leq 0.05)$ with all responses of plasma EAA and Tyr concentrations. The slope of $\Delta \mathrm{MP}$ was smallest for $\operatorname{Trp}(8 \%$, MR28) and highest for His in cows fed grass/legumebased rations (157\%, MR17). Note that only 14 studies (5 experiments) were available for corn silage-based rations; therefore, the influence of the type of forage should be interpreted cautiously.

The relationship between $\Delta \mathrm{MP}$ and the response of plasma His concentration was influenced positively $(P$ $=0.01)$ by the ratio MCPMP. For each unit $(\mathrm{kg} / \mathrm{d})$ increment in $\triangle \mathrm{MP}$ from its mean, responses of plasma
His concentration increased, on average, by 43, 121, and $181 \%$ for MCPMP at the first quartile, mean, and third quartile, respectively (MR16). Virtanen (1967) reported that cows fed protein-free diets had nearly 5 -fold lower plasma His concentrations compared with CTL cows (2-fold lower for Leu), and that the effect on His was related to extremely low His synthesis rates in rumen bacteria (not the case for Leu). Indeed, the concentration of His is low in rumen bacteria compared with grains and plant proteins (NRC, 2001). Therefore, the duodenal His flow is likely to be relatively low in diets with low grain or protein supplementation that rely heavily on microbial protein synthesis for MP supply. Such diets are typical for low-protein diets based either on grass (Kim et al., 1999; Vanhatalo et al., 1999) or corn silage (Lee et al., 2012; Giallongo et al., 2016). Lapierre et al. (2014b) reported that graded abomasal His infusions $(0,7.6,15.2$, and $22.8 \mathrm{~g} / \mathrm{d}$ ) elicited a dose-response increase in plasma His concentration, but the marginal response of plasma His concentration decreased as the rate of His infusion increased. The hepatic removal of His was related to the hepatic His influx and highest at the upper His infusion rate (Lapierre and Ouellet, 2015). In the current data set, the duodenal His flow in CTL cows was correlated nega- 
tively with the ratio MCPMP $(\mathrm{r}=-0.47 ; P<0.01$, df $=39$ ). Thus, one can hypothesize that small responses of plasma His concentration to $\triangle \mathrm{MP}$ could occur when the duodenal His flow is high (or MCPMP is low), because casein infusion would then stimulate the hepatic removal of His to a larger extent. Conversely, casein infusion could be associated with larger responses of plasma His concentration at low duodenal His flows (or high MCPMP).

The relationships between $\triangle \mathrm{MP}$ and responses of plasma Leu and Val concentrations were influenced negatively $(P \leq 0.02)$ by MP supply. For each unit $(\mathrm{kg} / \mathrm{d})$ increment in $\Delta \mathrm{MP}$ from its mean, responses of plasma Leu and Val concentrations increased, on average, by 29, 22, and $17 \%$, respectively (MR23); and by 148, 106, and 74\% (MR25) for MP supply at the first quartile, mean, and third quartile, respectively.

Overall, the relative effect of $\Delta \mathrm{MP}$ on the response of plasma group 2 AA concentration was nearly twice as much compared with that of group 1 AA (99 vs. 56\% at mean MP supply and MCPMP in MR26 and MR21, respectively). This difference is depicted in Figure 1 and likely reflects the low hepatic removal of group 2 AA versus group 1 AA (Hanigan, 2005; Lapierre et al., 2012).

\section{Casein Infusion and Responses of Plasma NEAA and Other Metabolite Concentrations}

The relationships between casein infusion and responses of plasma NEAA and other metabolite concentrations are reported in Table 7 . The effect of casein infusion on responses of plasma concentrations was positive $(P \leq 0.03)$ for Asn (6\%, MR30), Pro (63\%, MR36), and glucose $(1 \%$, MR39); negative $(P<0.01)$ for Gly ( $-6 \%$, MR34) and NS for Ala, Asp, Gln, Glu, Ser, NEFA $(P=0.12)$, and BHB. In agreement with our results, casein infusion had opposite effects on plasma Pro and Gly concentrations in Whitelaw et al. (1986), Miettinen and Huhtanen (1997), and Raggio et al. (2006). Note that few data were available for Asn, Pro, and BHB; therefore, results should be interpreted cautiously.

The relationships between $\triangle \mathrm{MP}$ and responses of plasma Ala, Asn, Asp, Glu, and Gln concentrations were NS. The relationship was highest for Pro; for each unit $(\mathrm{kg} / \mathrm{d})$ increment in $\Delta \mathrm{MP}$ from its mean, responses of plasma Pro concentration increased, on average, by 67\% (MR36). Guinard and Rulquin (1994) suggested that an increase in plasma Pro concentration might be related to the high Pro proportion in the casein AA profile (10.3\%; Galindo et al., 2011) compared with that in ruminal bacteria (3.7\%; Clark et al., 1992).
The relationships for Gly and Ser were influenced positively $(P \leq 0.05)$ by MP balance and differed $(P \leq$ $0.03)$ between stages of lactation. For each unit $(\mathrm{kg} / \mathrm{d})$ increment in $\triangle \mathrm{MP}$ from its mean, responses of plasma Gly and Ser concentrations increased, on average, respectively, by $-19,-5$, and $8 \%$ (MR34) and by 0,18 , and 34\% (MR37) for MP balance at the first quartile, mean, and third quartile, respectively. Pertaining to stage of lactation, the negative relationship between $\triangle \mathrm{MP}$ and responses of plasma Gly concentration in early lactating cows $(-36 \%, P=0.03$, MR35) could reflect a greater demand of Gly for glucose synthesis to support milk lactose yield. On the other hand, the positive relationship between $\Delta \mathrm{MP}$ and the response of plasma Ser concentration in mid- to late-lactating cows $(38 \%, P=0.01$, MR38) might reflect a lesser demand of Ser for MTPY synthesis. The demand for Gly and Ser is likely to be important in early lactation, as Gly and Ser are primary sources of methylneogenesis and gluconeogenesis (Armentano, 1994; Girard and Matte, 2005). Black et al. (1990) also reported that Gly and Ser were the least oxidized NEAA in early-lactating cows, an effect linked to their essential roles as precursors of protein and metabolite synthesis (e.g., choline, purines, porphyrins, creatinine, C-1 pool carbon, and glucose).

The relationships between $\triangle \mathrm{MP}$ and responses of plasma glucose, NEFA, and BHB concentrations were NS. Overall, the effect of casein infusion was more variable on the responses of plasma NEAA concentration compared with that of EAA. The relationship between $\triangle \mathrm{MP}$ and plasma Gly and Ser concentrations were influenced by the physiological status. The relationship between $\triangle \mathrm{MP}$ and plasma Pro concentration warrants further investigation.

\section{CONCLUSIONS}

Increased MP supply, achieved through postruminal casein infusion, was an important explanatory variable either by itself for some production responses (e.g., milk yield) or in interaction with MP supply or MP balance for other responses (e.g., MTPY). Meta-regressions showed that the relationship between $\triangle \mathrm{MP}$ and the response of MTPY was highest when MP supply was low or MP balance was negative. The relationships between $\triangle \mathrm{MP}$ and responses of plasma AA concentrations were influenced by the plane of nutrition (MP supply or MP balance), the stage of lactation (early vs. mid/late), the type of forage (grass/legume- vs. corn silage-based diets), and the ratio of microbial protein in MP supply. Including the variations of MTPY responses to increased protein supply according to dietary and cow 
characteristics can improve models currently used to balance dairy rations for protein and AA.

\section{ACKNOWLEDGMENTS}

The authors thank Steve Méthot (Research and Development Centre; Sherbrooke, QC, Canada) for his statistical advice and contribution for this manuscript. The authors also acknowledge the invaluable contribution of Wolfgang Viechtbauer (Maastricht University, Maastricht, the Netherlands), who authored the metafor package. Appreciation is also extended to the Dairy Farmers of Canada (Ottawa, Canada), Agriculture and Agri-Food Canada, and Valacta for their financial support.

\section{REFERENCES}

Abramson, S. M., I. Bruckental, S. Zamwel, and A. Arieli. 2002. Effect of abomasally infused casein on post-ruminal digestibility of total non-structural carbohydrates and milk yield and composition in dairy cows. Anim. Sci. 74:347-355.

Aikman, P. C., C. K. Reynolds, D. J. Humphries, D. E. Beever, and J. C. MacRae. 2002. Milk protein response to abomasal or mesenteric vein essential amino acid infusion in lactating dairy cows. J. Dairy Sci. 85:1079-1084.

Armentano, L. E. 1994. Impact of metabolism by extragastrointestinal tissues on secretarory rate of milk proteins. J. Dairy Sci. $77: 2809-2820$.

Arriola Apelo, S. I., J. R. Knapp, and M. D. Hanigan. 2014. Invited review: Current representation and future trends of predicting amino acid utilization in the lactating dairy cow. J. Dairy Sci. 97:4000-4017.

Bionaz, M., W. Hurley, and J. Loor. 2012. Milk protein synthesis in the lactating mammary gland: insights from transcriptomics analyses. Pages 285-324 in Milk Protein Chapter 11. W. L. Hurley, ed. InTech, Rijeka, Croatia.

Black, A. L., R. S. Anand, M. L. Bruss, C. A. Brown, and J. A. Nakagiri. 1990. Partitioning of amino acids in lactating cows: oxidation to carbon dioxide. J. Nutr. 120:700-710.

Broderick, G. A., T. Kowalczyk, and L. D. Satter. 1970. Milk production response to supplementation with encapsulated methionine per os or casein per abomasum. J. Dairy Sci. 53:1714-1721.

Chalmers, M. I., D. P. Cuthbertson, and R. L. M. Synge. 1954. Ruminal ammonia formation in relation to the protein requirement of sheep. I. Duodenal administration and heat processing as factors influencing fate of casein supplements. J. Agric. Sci. (Camb.) 44:254-262.

Chamberlain, D. G., and J. M. Yeo. 2003. Effects of amino acids on milk production. Pages 367-387 in Amino Acids in Animal Nutrition. J. P. D'Mello, ed. CAB International, Wallingford, UK.

Choi, C. W., K. H. Kim, and S. H. Choi. 2013. Effects of abomasal infusions of casein, glucose or starch on milk production and blood metabolites in dairy cows. J. Agric. Life Sci 47:81-89.

Choung, J.-J., and D. G. Chamberlain. 1993a. The effects of abomasal infusions of casein or soya-bean-protein isolate on the milk production of dairy cows in mid-lactation. Br. J. Nutr. 69:103-115.

Choung, J.-J., and D. G. Chamberlain. 1993b. Effects of addition of lactic acid and post-ruminal supplementation with casein on the nutritive value of grass silage for milk production in dairy cows. Grass Forage Sci. 48:380-386.

Choung, J.-J., and D. G. Chamberlain. 1995. Effects of abomasal infusions of sodium caseinate, a hydrolysate of casein or a correspond- ing mixture of free amino acids on milk yield and composition in dairy cows. J. Dairy Res. 62:29-37.

Clark, J. H. 1975. Lactational responses to postruminal administration of proteins and amino acids. J. Dairy Sci. 58:1178-1197.

Clark, J. H., T. H. Klusmeyer, and M. R. Cameron. 1992. Microbial protein synthesis and flows of nitrogen fractions to the duodenum of dairy cows. J. Dairy Sci. 75:2304-2323.

Clark, J. H., H. R. Spires, R. G. Derrig, and M. R. Bennink. 1977. Milk production, nitrogen utilization and glucose synthesis in lactating cows infused postruminally with sodium caseinate and glucose. J. Nutr. 107:631-644.

DePeters, E. J., and J. P. Cant. 1992. Nutritional factors influencing the nitrogen composition of bovine milk: A review. J. Dairy Sci. 75:2043-2070.

Derrig, R. G., J. H. Clark, and C. L. Davis. 1974. Effect of abomasal infusion of sodium caseinate on milk yield, nitrogen utilization and amino acid nutrition of the dairy cow. J. Nutr. 104:151-159.

Dhiman, T. R., C. Cadorniga, and L. D. Satter. 1993. Protein and energy supplementation of high alfalfa silage diets during early lactation. J. Dairy Sci. 76:1945-1959.

Doepel, L., D. Pacheco, J. J. Kennelly, M. D. Hanigan, I. F. Lopez, and H. Lapierre. 2004. Milk protein synthesis as a function of amino acid supply. J. Dairy Sci. 87:1279-1297.

Galindo, C. E., D. R. Ouellet, D. Pellerin, S. Lemosquet, I. OrtiguesMarty, and H. Lapierre. 2011. Effect of amino acid or casein supply on whole-body, splanchnic, and mammary glucose kinetics in lactating dairy cows. J. Dairy Sci. 94:5558-5568.

Giallongo, F., M. T. Harper, J. Oh, J. C. Lopes, H. Lapierre, R. A. Patton, C. Parys, I. Shinzato, and A. N. Hristov. 2016. Effects of rumen-protected methionine, lysine and histidine on lactation performance of dairy cows. J. Dairy Sci. 99:4437-4452.

Girard, C. L., and J. J. Matte. 2005. Folic acid and vitamin $B_{12}$ requirements of dairy cows: A concept to be revised. Livest. Prod. Sci. 98:123-133.

Griinari, J. M., M. A. McGuire, D. A. Dwyer, D. E. Bauman, D. M. Barbano, and D. L. Palmquist. 1997. Role of insulin in the regulation of milk protein synthesis in dairy cows. J. Dairy Sci. 80:2361-2371.

Guinard, J., and H. Rulquin. 1994. Effect of graded levels of duodenal infusions of casein on mammary uptake in lactating cows. 2. Individual amino acids. J. Dairy Sci. 77:3304-3315.

Guinard, J., H. Rulquin, and R. Vérité. 1994. Effect of graded levels of duodenal infusions of casein on mammary uptake in lactating cows. 1. Major nutrients. J. Dairy Sci. 77:2221-2231.

Hanigan, M. D. 2005. Quantitative aspects of ruminant splanchnic metabolism as related to predicting animal performance. Anim. Sci. 80:23-32.

Hanigan, M. D., J. P. Cant, D. C. Weakley, and J. L. Beckett. 1998. An evaluation of postabsorptive protein and amino acid metabolism in the lactating dairy cow. J. Dairy Sci. 81:3385-3401.

Hanigan, M. D., C. K. Reynolds, D. J. Humphries, B. Lupoli, and J. D. Sutton. 2004. A model of net amino acid absorption and utilization by the portal-drained viscera of the lactating dairy cow. J. Dairy Sci. 87:4247-4268.

Higgins, J. P. T., and S. G. Thompson. 2002. Quantifying heterogeneity in a meta-analysis. Stat. Med. 21:1539-1558.

Huhtanen, P., and A. N. Hristov. 2009. A meta-analysis on the effects of dietary protein concentration and degradability on milk protein yield and milk $\mathrm{N}$ efficiency in dairy cows. J. Dairy Sci. 92:3222-3232.

Huhtanen, P., and A. N. Hristov. 2010. Effects of energy and protein supply on milk protein yield responses in dairy cows. Pages 287298 in Energy and Protein Metabolism and Nutrition. G. Matteo Grovetto, ed. EAAP Publ. No. 127. Wageningen Academic Publishers, Wageningen, the Netherlands.

Huhtanen, P., H. O. Miettinen, and V. F. J. Toivonen. 1997. Effects of silage fermentation and post-ruminal casein supplementation in lactating dairy cows: 1 -Diet digestion and milk production. J. Sci. Food Agric. 74:450-458. 
Hurtaud, C., H. Rulquin, and R. Verite. 1993. Effect of infused volatile fatty acids and caseinate on milk composition and coagulation in dairy cows. J. Dairy Sci. 76:3011-3020.

INRA (Institut National de la Recherche Agronomique). 2007. INRAtion - Version professionnelle intégrale. 40 ed. Educagri éditions, Theix, France.

Khalili, H., and P. Huhtanen. 2002. Effect of casein infusion in the rumen, duodenum or both sites on factors affecting forage intake and performance of dairy cows fed red clover-grass silage. J. Dairy Sci. 85:909-918.

Kim, C.-H., J.-J. Choung, and D. G. Chamberlain. 1999. Determination of the first-limiting amino acid for milk production in dairy cows consuming a diet of grass silage and a cereal-based supplement containing feather meal. J. Sci. Food Agric. 79:1703-1708.

Kleinbaum, D. G., L. L. Kupper, K. E. Muller, and A. Nizam. 1998 Confounding and interaction in regression. Pages 186-211 in Applied Regression Analysis and Other Multivariable Methods. G. Kleinbaum, L. L. Kupper, A. Nizam, and K. E. Miller, ed. Duxbury Press, Pacific Grove, CA.

Konstantopoulos, S. 2011. Fixed effects and variance components estimation in three-level meta-analysis. Res. Synth. Methods 2:61-76.

Lapierre, H., R. Berthiaume, G. Raggio, M. C. Thivierge, L. Doepel, D. Pacheco, P. Dubreuil, and G. E. Lobley. 2005. The route of absorbed nitrogen into milk protein. Anim. Sci. 80:11-22.

Lapierre, H., L. Doepel, D. Pacheco, and D. R. Ouellet. 2014a. Amino acid requirements and post-absorptive metabolism in cattle: Implications for ration formulation. Pages 166-178 in Proc. Florida Ruminant Nutrition Symposium. University of Florida, Gainesville.

Lapierre, H., G. E. Lobley, L. Doepel, G. Raggio, H. Rulquin, and S. Lemosquet. 2012. Triennial Lactation Symposium: Mammary metabolism of amino acids in dairy cows. J. Anim. Sci. 90:1708-1721.

Lapierre, H., and D. R. Ouellet. 2015. How the efficiency of utilization of histidine (His) varies with supply in dairy cows? J. Dairy Sci. 98(Suppl. 2):609. (Abstr.)

Lapierre, H., D. R. Ouellet, and G. E. Lobley. 2014b. Estimation of histidine requirement in lactating dairy cows. J. Dairy Sci. 97(ESuppl. 1):757. (Abstr.)

Larsen, M., C. Galindo, D. R. Ouellet, G. Maxin, N. B. Kristensen, and H. Lapierre. 2015. Abomasal amino acid infusion in postpartum dairy cows: Effect on whole-body, splanchnic, and mammary amino acid metabolism. J. Dairy Sci. 98:7944-7961.

Larsen, M., H. Lapierre, and N. B. Kristensen. 2014. Abomasal protein infusion in postpartum transition dairy cows: Effect on performance and mammary metabolism. J. Dairy Sci. 97:5608-5622.

Lee, C., A. N. Hristov, T. W. Cassidy, K. S. Heyler, H. Lapierre, G. A. Varga, M. J. de Veth, R. A. Patton, and C. Parys. 2012. Rumenprotected lysine, methionine, and histidine increase milk protein yield in dairy cows fed a metabolizable protein-deficient diet. J. Dairy Sci. 95:6042-6056.

Lemosquet, S., G. Raggio, G. E. Lobley, H. Rulquin, J. Guinard-Flament, and H. Lapierre. 2009. Whole-body glucose metabolism and mammary energetic nutrient metabolism in lactating dairy cows receiving digestive infusion of casein and propionic acid. J. Dairy Sci. 92:6068-6082.

Martineau, R., C. Côrtes, I. Ortigues-Marty, D. R. Ouellet, and H. Lapierre. 2014. Evaluation of equations predicting the net portal appearance of amino acid nitrogen in ruminants. J. Dairy Sci. $97: 1670-1681$

Martineau, R., D. R. Ouellet, E. Kebreab, and H. Lapierre. 2016. Casein infusion rate influences feed intake differently depending on metabolizable protein balance in dairy cows: A multilevel metaanalysis. J. Dairy Sci. 99:2748-2761.

Martineau, R. D. Sauvant, D. R. Ouellet, C. Côrtes, J. Vernet, I. Ortigues-Marty, and H. Lapierre. 2011. Relation of net portal flux of nitrogen compounds with dietary characteristics in ruminants: A meta-analysis approach. J. Dairy Sci. 94:2986-3001.

Miettinen, H. O., and P. Huhtanen. 1997. Effects of silage fermentation and post-ruminal casein supplementation in lactating dairy cows: 2-Energy metabolites and plasma amino acids. J. Sci. Food Agric. 74:459-468.
Moshel, Y., R. E. Rhoads, and I. Barash. 2006. Role of amino acids in translational mechanisms governing milk protein synthesis in murine and ruminant mammary epithelial cells. J. Cell. Biochem. 98:685-700.

Neter, J., W. Wasserman, and G. A. Whitmore. 1988. Random variables. Pages 146-184 in Applied Statistics. 3rd edition. Allyn and Bacon Inc., Newton, MA.

NRC. 2001. Nutrient Requirements of Dairy Cattle. 7th Rev. Ed. Natl. Acad. Science, Washington, DC.

Oldham, J. D., G. E. Lobley, B. A. König, D. S. Parker, and R. W Smith. 1980. Amino acid metabolism in lactating dairy cows early in lactation. Pages 458-463 in Protein Metabolism and Nutrition. EAAP No. 27. H. J. Oslage and K. Rohr, ed. Information Centre of Bundesforschungsanstalt für Landwirtschaft, Braunschweig, Germany.

Ørskov, E. R., D. A. Grubb, and R. N. B. Kay. 1977. Effect of postruminal glucose or protein supplementation on milk yield and composition in Friesian cows in early lactation and negative energy balance. Br. J. Nutr. 38:397-405.

Patton, R. A., A. N. Hristov, C. Parys, and H. Lapierre. 2015. Relationships between circulating plasma concentrations and duodenal flows of essential amino acids in lactating dairy cows. J. Dairy Sci. 98:4707-4734

R Core Team. 2014. R: A Language and Environment for Statistical Computing. R Foundation for Statistical Computing. Vienna, Austria. www.R-project.org.

Raggio, G., G. E. Lobley, S. Lemosquet, H. Rulquin, and H. Lapierre. 2006. Effect of casein and propionate supply on whole body protein metabolism in lactating dairy cows. Can. J. Anim. Sci. 86:81-89.

Relling, A. E., and C. K. Reynolds. 2008. Abomasal infusion of casein, starch and soybean oil differentially affect plasma concentrations of gut peptides and feed intake in lactating dairy cows. Domest. Anim. Endocrinol. 35:35-45.

Rogers, J. A., J. H. Clark, T. R. Drendel, and G. C. Fahey Jr. 1984. Milk production and nitrogen utilization by dairy cows infused postruminally with sodium caseinate, soybean meal, or cottonseed meal. J. Dairy Sci. 67:1928-1935.

Rulquin, H. 1986. Influence de l'équilibre en acides aminés de trois protéines infusées dans l'intestin grêle, sur la production laitière de la vache. Reprod. Nutr. Dev. 26:347-348.

Sauvant, D., G. Cantalapiedra-Hijar, L. Delaby, J.-B. Daniel, P. Faverdin, and P. Nozière. 2015. Actualisation des besoins protéiques des ruminants et détermination des réponses des femelles laitières aux apports de protéines digestibles dans l'intestin. INRA Prod. Anim. 28:347-368.

Schwab, C. G., C. K. Bozak, N. L. Whitehouse, and M. M. A. Mesbah. 1992. Amino acid limitation and flow to duodenum at four stages of lactation. 1. Sequence of lysine and methionine limitation. J. Dairy Sci. 75:3486-3502.

Seymour, W. M., C. E. Polan, and J. H. Herbein. 1990. Effects of dietary protein degradability and casein or amino acid infusions on production and plasma amino acids in dairy cows. J. Dairy Sci. 73:735-748.

Steel, R. G. D., J. H. Torrie, and D. A. Dickey. 1997. Principles and Procedures of Statistics: A Biometrical Approach. 3rd ed. McGraw-Hill Book Co., New York, NY.

Vanhatalo, A., P. Huhtanen, V. Toivonen, and T. Varvikko. 1999 Response of dairy cows fed grass silage diets to abomasal infusions of histidine alone or in combinations with methionine and lysine. J. Dairy Sci. 82:2674-2685.

Vanhatalo, A., T. Varvikko, and P. Huhtanen. 2003a. Effects of casein and glucose on responses of cows fed diets based on restrictively fermented grass silage. J. Dairy Sci. 86:3260-3270.

Vanhatalo, A., T. Varvikko, and P. Huhtanen. 2003b. Effects of various glucogenic sources on production and metabolic responses of dairy cows fed grass silage-based diets. J. Dairy Sci. 86:3249-3259.

Viechtbauer, W. 2010. Conducting meta-analyses in R with the metafor package. J. Stat. Softw. 36:1-48. 
Viechtbauer, W. 2016a. rma.mv: Meta-analysis via multivariate/ multilevel linear (mixed-effects) models. Accessed May 15, 2016. https://rdrr.io/cran/metafor/man/rma.mv.html.

Viechtbauer, W. 2016b. Meta-analysis with R: the metafor package. Accessed May 20, 2016. http://www.wvbauer.com/lib/exe/fetch. php/talks:2016_viechtbauer\%20_gesis_ma_with_metafor.pdf.

Viechtbauer, W. 2016c. The metafor package. A meta-analysis package for R. Konstantopoulos (2011). Accessed May 10, 2016. http:/ /www. metafor-project.org/doku.php/analyses:konstantopoulos2011.

Viechtbauer, W. 2016d. The metafor package. I^2 for multilevel and multivariate models. Accessed Apr. 20, 2017. http://www.metaforproject.org/doku.php/tips:i2_multilevel_multivariate.

Vik-Mo, L., R. S. Emery, and J. T. Huber. 1974a. Milk protein production in cows abomasally infused with casein or glucose. J. Dairy Sci. 57:869-877.
Vik-Mo, L., J. T. Huber, W. G. Bergen, R. E. Lichtenwalner, and R. S. Emery. 1974b. Blood metabolites in cows abomasally infused with casein or glucose. J. Dairy Sci. 57:1024-1030.

Virtanen, A. I. 1967. Chapter 10-The production of milk on proteinfree rations. Pages 185-212 in Urea as a Protein Supplement. 1st ed. M. H. Briggs, ed. Pergamon Press, Long Island City, NY.

Volden, H., N. I. Nielsen, M. Åkerlind, and A. J. Rygh. 2011. NorForThe Nordic Feed Evaluation System. EAAP publication No. 130. $\mathrm{H}$. Volden, ed. Wageningen Academic Publishers, Wageningen, the Netherlands.

Whitelaw, F. G.. J. S. Milne, E. R. Ørskov, and J. S. Smith. 1986. The nitrogen and energy metabolism of lactating cows given abomasal infusions of casein. Br. J. Nutr. 55:537-556.

Wickham, H. 2009. ggplot2: Elegant Graphics for Data Analysis. Springer-Verlag, New York, NY. 